\title{
CANADA'S WELCOMERS \\ BUILDING RELATIONSHIPS BETWEEN NEWCOMER SETTLEMENT ORGANIZATIONS AND INDIGENOUS ORGANIZATIONS AND PEOPLES
}

\author{
By \\ Rachel Reesor BA \& BEd Nipissing University, 2013 \\ A Major Research Paper \\ Presented to Ryerson University \\ In partial fulfillment of the requirements for the degree of \\ Master of Arts \\ In the Program of Immigration and Settlement Studies
}

Toronto, Ontario, Canada, 2019

(C) Rachel Reesor 2019 


\section{AUTHOR'S DECLARATION FOR ELECTRONIC SUBMISSION OF A MAJOR RESEARCH PAPER (MRP)}

I hereby declare that I am the sole author of this Major Research Paper. This is a true copy of the MRP, including any required final revisions, as accepted by my examiners.

I authorize Ryerson University to lend this MRP to other institutions or individuals for the purpose of scholarly research.

I further authorize Ryerson University to reproduce this MRP by photocopying or by other means, in total or in part, at the request of other institutions or individuals for the purpose of scholarly research.

I understand that my MRP may be made electronically available to the public.

Rachel Reesor 


\title{
CANADA'S WELCOMERS: BUILDING RELATIONSHIPS BETWEEN NEWCOMER SETTLEMENT ORGANIZATIONS AND INDIGENOUS ORGANIZATIONS AND PEOPLES
}

\author{
Rachel Reesor \\ Masters of Arts 2019 \\ Immigration and Settlement Studies \\ Ryerson University
}

\begin{abstract}
Multiculturalism, part of Canada's national identity, continues to integrate newcomers into mainstream society, which excludes Indigenous people. If Indigenous people became the welcomers of Canada by replacing multiculturalism with Treaties, they would be placed at the forefront of Canada's national identity and acknowledged for being the First People of Canada rather than ignored. The purpose of my paper is to argue that settlement services should have to build relationships with Indigenous organizations and people in order to build relationships between Indigenous people and newcomers, that would allow newcomers to be better informed about Canada's history and Canada's Indigenous people. Within my research I will be critically analyzing six settlement organizations that have begun the process of building these relationships and present the benefits and challenges to building these relationships as well as what their next steps are for moving forward with this relationship. My findings will help to present recommendations for the government of Canada to assist in building these relationships.
\end{abstract}

Keywords:

Indigenous, newcomer, settlement services, decolonization, Indigenous resurgence, multiculturalism, colonialism, settler colonialism 


\section{ACKNOWLEDGEMENTS}

I would like to thank Harald Bauder for his guidance and patience with me as I ventured through this process. He believed I could complete my MRP with success when I often did not. I would like to thank Sedef Arat-Koc for her kindness, assistance and general interest in my topic. I would also like to thank all of my interviewees for I would not have been able to provide the rich data I did without their participation and time. Thank you to my family members especially my parents. You have always supported me and believed in me throughout all of my trials and tribulations. Thank you to the 2017/2018 ISS cohort, you were all wonderful people who supported and encouraged my topic and me since day one. I'm so lucky to have met all of you. And lastly, I want to thank those people who are near and dear to me who I met in the Northwest Territories in Behchoko and Wekweti. If I never had the opportunity to live up north I may have never learned the importance of Indigenous knowledge, history and voices within Canadian policy, about my role as a white Canadian settler and about the importance of learning and allyship. 


\section{DEDICATION}

I would like to dedicate this paper to all of those people and organizations, especially Canada's Indigenous people, who work towards decolonizing Canada. Those fighting against Canada's oppressive system are strong and willful people who deserve recognition. My hope is that my paper starts the conversation about how Indigenous organizations and people can begin to be placed at the forefront of settlement services

and immigration policies. It is time for the State to take ownership of its past and begin to recognize and empower all individuals. 


\section{TABLE OF CONTENTS}

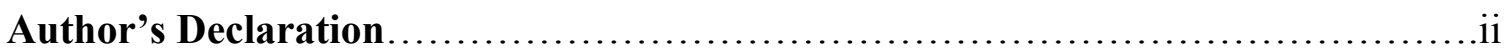

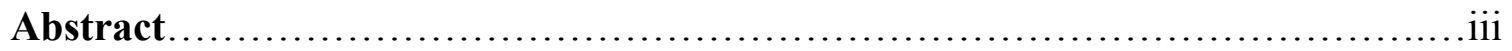

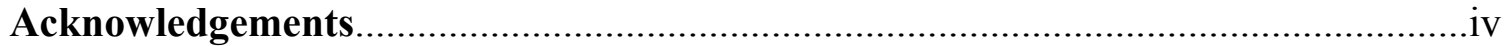

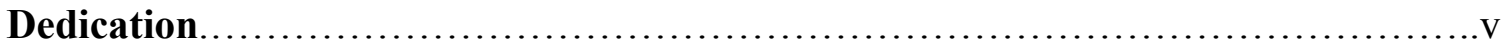

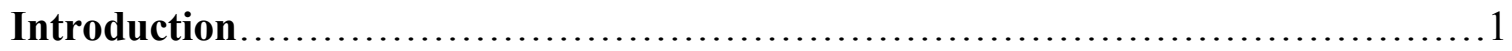

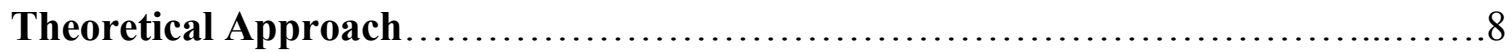

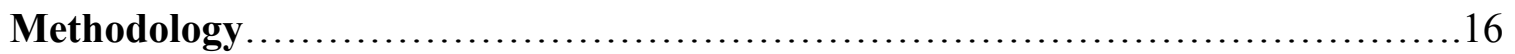

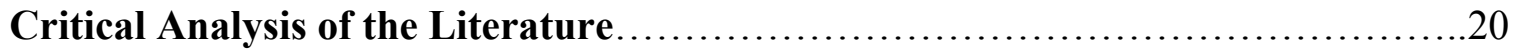

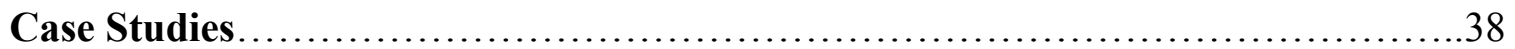

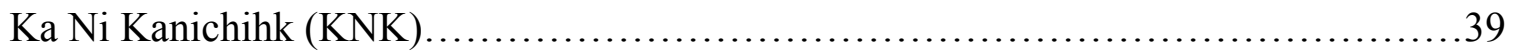

Vancouver Dialogue Project..........................................................

KAIROS Canadian Ecumenical Justice Initiatives.................................46

Canadian Roots Exchange (CRE) ..................................................49

Ontario Council of Agencies Serving Immigrants (OCASI) .........................50

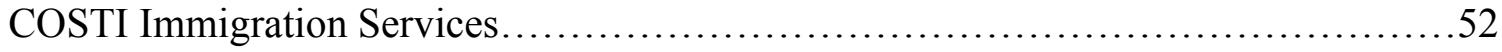

Benefits, Challenges, and Next Steps for the Future.............................53

Benefits of Building Relationships between Settlement Services and Indigenous

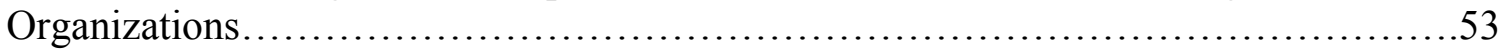

Challenges of Building Relationships between Settlement Services and Indigenous

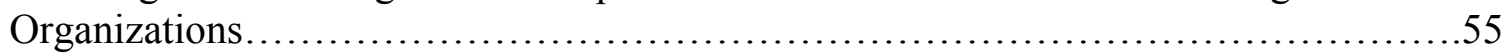

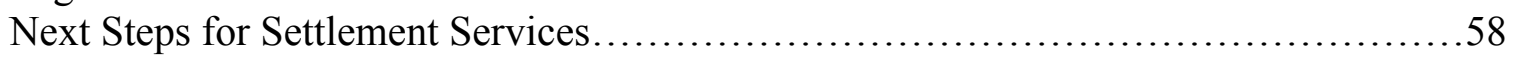

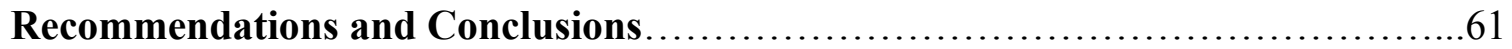

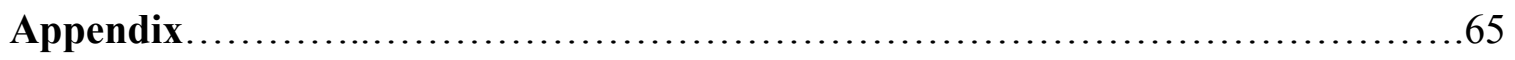

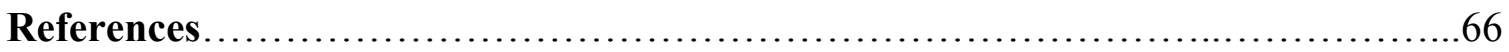




\section{INTRODUCTION}

Canada is perceived as a welcoming and diverse country to many, due to the large number of immigrants entering Canada yearly. The average annual level of immigration between 2000-2015 was roughly 250,000 and it is estimated to be near 300,000 for 2017 (CCR, 2017). Unfortunately, the Canadian state tends to ignore the historical and present day growth of the Indigenous population as their needs for clean water and proper housing are rarely addressed and they are never consulted about immigration policies and numbers. Historically, European settlers did not only displace the First People of Canada, but attempts were made to actively eradicate them so settlers could gain power over resources, control over land and establish their race as superior to others. For centuries, Indigenous people have been excluded from the communities that settlers built in Canada (MacDonald, 2014). Sadly, as a Canadian myself growing up in Fenelon Falls, Ontario, I knew little about the despair of Indigenous people for the majority of my life. It was not until I moved to the Northwest Territories to become a teacher that I realized the effects settler-colonialism has on Indigenous people. I quickly realized how oblivious I had been to the detrimental policies, acts and events that led to creating Canada. As a settler of Canada, I have been living on appropriated Indigenous land. I also must acknowledge that as a settler I have privileges and rights that are denied to many Indigenous people (Lawrence \& Dua, 2005, p. 123).

Simpson (2011) explains that "reconciliation is a process of regeneration that will take many years to accomplish" (p. 22), but this will not happen if responsibility is not taken by the state and by the citizens of Canada. She explains how Canadians who do not understand the injustices of their occupation of the land and the Canadian State who 
refuses to make any adjustments to its current relationship with Indigenous peoples are similar to an abusive spousal relationship: when one person is being abused by their partner and the abuser says they want to change but in fact does not take responsibility or change, then the abuse continues; saying "sorry" so they can feel less guilty does not end the abuse (Simpson, 2011, p. 21). My motivation for writing this Major Research Paper is not only my conviction that the Canadian State and its citizens need to take responsibly to stop the abuse by implementing the recommendations of the Truth and Reconciliation Commission (TRC), but that the state needs to create ways to mitigate the effects of ongoing settlement of newcomers on Indigenous land with the active involvement of Indigenous leaders. I must additionally acknowledge that not all Indigenous organizations and people agree with the Truth and Reconciliation Commission and not all Indigenous people want to be the welcomers of Canada, as they may see it as being placed at the forefront of a colonial country, which they would rather disassociate from. Instead of decolonizing the state and government system, which I believe Canada is currently far from achieving, I am focusing on settlement sectors. By first educating newcomers that this land is Indigenous land and starting the conversation around this is the first step to decolonizing. Settlement services assist and inform newcomers in order to integrate them into Canadian society. Therefore, my paper will present the need for settlement services to work on building relationships with Indigenous organizations and people so that newcomers are informed about the First People of Canada and to develop programming and activities that allow Indigenous people and newcomers to build relationships between each other. 
I am neither a newcomer nor an Indigenous person but I feel that it is my duty as a Canadian to begin to unlearn and start to decolonize myself in order to properly become an ally alongside Indigenous people. When decolonizing myself I need to question my colonial perspectives and beliefs as well as be open to learning from others while acknowledging my privilege. I need to be actively aware of my colonial mindset and actively resist the forces of colonialism, while seeking Indigenous knowledge and perspectives. Throughout this process I had many moments where I felt so uncomfortable with this topic and my research that I broke down in tears asking myself: should I be writing this paper? I am not Indigenous, maybe this is not my place to speak? I did not want this paper to be just another paper written by another white person about Indigenous people and thereby perpetuate settler colonialism. For me, these thoughts have been essential to process and go through because colonialism is an uncomfortable topic for settler-colonial subjects, such as myself (Lowman \& Barker, 2015, p. 106). It would have been problematic if this Major Research Paper were comfortable for me to write. Instead, the ideas presented in this paper were extremely difficult for me to process, understand and present because unsettling colonialism is a process, which should never be a done from a place of comfort (De Leeuw, Greenwood \& Lindsay, 2013, p. 391; Lowman \& Barker, 2015, p. 106). Unsettle colonialism means to start questioning what is often accepted in our colonial country as "right" and begin to look at alternative ways to resist and move away from colonialism. Rather than being an innocent settler, who dismisses their feelings of guilt or responsibility without having to give up land, power or privilege, or change at all, I want to be a settler that goes through the uncomfortable, unlearning stage and begins to change (Tuck \& Yang, 2012, p. 10). In 
this paper I use my position as a settler as a tool for confronting the problems and injustices experienced by Indigenous Peoples in Canada today (Lowman \& Barker, 2016, p. 2). I wanted to ensure I wrote this paper with empathy, consideration and with the ability to unlearn my Western, colonial ways.

In this paper, I aim to present ways in which Canadian society can frame not themselves but Indigenous people as the welcomers of Canada by researching how settlement services and nonprofit organizations have begun to work alongside Indigenous organizations and people to create opportunities for newcomer and Indigenous people to build relationships. The guiding research questions are: how can or how have settlement services or nonprofit organizations worked alongside Indigenous organizations and people? And what are the benefits and challenges of building these relationships between organizations and between newcomers and Indigenous people? I conducted a literature review and interviewed participants from settlement organizations in order to address these questions. I interviewed organizations that started this process in order to identify their main benefits, challenges and next steps in hopes of presenting broad concepts that other organizations across Canada can adapt and implement in order to begin developing authentic relationships with Indigenous people to create information, programs and workshops for newcomers. To develop an authentic relationship, settlement services need to ensure that the relationship is ongoing, that the knowledge and information of others are valued and supported, and that the relationship is not exploited simply to fill a mandate. I hoped these interviews would also help frame how settlement services and nonprofit organizations can begin to decolonize and start this reconciliation process. Throughout this process, I have tried to address that I do not do more harm than good; as 
Stanley, Arat-Koc, Bertram and King (2014) state: non-Indigenous people must "listen to what we are saying; strive to understand our perspectives; critically reflect on your own assumptions about Indigenous peoples; and let us determine our best interests" (par. 33). Originally when I began this paper I wanted to focus on listening to and understanding Indigenous perspectives, but, unfortunately, I failed at this attempt as I was unable to interview any Indigenous organizations or people. Instead of incorporating Indigenous voices into my research, I focused this paper on what Canadian settlement organizations can do to be open to building relationships with Indigenous organizations and people and how they can begin to incorporate Indigenous voices into their programming.

Before continuing, it is important to identify some main terms: Indigenous people refers to Metis, First Nation, and Inuit, which also recognizes the fact that they are the original inhabitants of Canada (Root, 2014, p. 7; Corntassel \& Alfred, 2005, p. 597). I will not be using the term Aboriginal because the root of the word 'ab' means 'not,' therefore, Aboriginal implies not original or abnormal (Mark, 2014). Thus, Indigenous is a term that is more accepting of Indigenous people's identity. Newcomers refers to refugees, permanent residents, and immigrants who do not have citizenship status. This definition ensures that I am focusing on people who are more likely to be using settlement services. Next, is the term settler, which I will use to refer to all those who are non-Indigenous. This term is widely debated because many authors believe racialized newcomers and minority people should not be considered settlers because they are marginalized, do not have the same privileges as white settlers and their migration may not have been voluntary (Kasparian, 2012; Sium, Desai, Ritskes, 2012; Lawrence \& Dua, 
2005; Stanley, Arat-Koc, Bertram, King, 2014; Sharma \& Wright, 2008/2009). Although I agree that racialized newcomers and minority people do not have the same privileges as white settlers, I still believe they are settlers because they are living on stolen land that does not belong to anyone except Canada's Indigenous people (Snelgrove, Dhamoon \& Corntassel, 2014). Colonialism is the subordination of a group of people for the purpose of claiming land and resources while Settler Colonialism is about displacement and replacement, it is rooted in the elimination of Indigenous people from the land for the purpose of replacing control and identity with the white settler colony (Smith, 2012, p. 23; Wolfe, 2006). This process is ongoing and continues. Multiculturalism is a framework for nation building that will be used as a representation of a part of Canada's national identity (Winter, 2007). This identity presents itself as being inclusive and accepting of everyone but in actuality it does not address inequality, therefore, it separates people and reproduces unequal groups. The discourse of multiculturalism seeks to assimilate diversities into a singular Canadian identity (Walia, 2012). Reconciliation is about acknowledging the past, so we do not repeat it and working towards restoring a balanced relationship between Indigenous people and settlers (Truth and Reconciliation Commission, 2015). Reconciliation has many meanings depending on the context. According to Coulthard (2017) reconciliation is a form of healing for Indigenous people and seen as nation to nation reconciliation, while the settler state often deems reconciliation as reconciling the existence of Indigenous people with the sovereignty of the crown. The state often places Canada as having supreme rights, which continues the colonial system. I agree with Joyce Green's (2016) version of reconciliation, "a state of relational peace achieved by processes and practices intended to convey contrition, 
empathy, and commitment to transformation from a damaged to a better relationship" ( $p$. 4) in hopes of creating an equitable future. In order to explain relationship-building between Indigenous people and settlers I will using words such as involve, include, collaborate and ally rather than solidarity as we still have a long way to go before solidarity will be reached within Canada. It is important to acknowledge that ally will be used as a verb rather than a noun because constant action is needed to be an Indigenous ally (Lowman \& Barker, 2015, p. 116).

Within my paper I will address my theoretical framework on decolonization and Indigenous resurgence to establish the perspective I will be writing my paper from. In the next section, I will address my methodology, which explains my literature review and interview process. Then, I will present a critical literature review about how Indigenous people are excluded from part of Canada's national identity, multiculturalism and present a new possible framework for Canada's national identity that is more inclusive. Within my case studies I will explain what specific settlement services and nonprofit organizations are doing to build relationships with Indigenous organizations and people. Finally, I will present the information from my interviewees by explaining the main themes that were revealed in relation to the benefits and challenges of working alongside Indigenous organizations and what they believe their next steps are in terms of continuing to build these relationships. Lastly, I will present the interviewees and my own recommendations for what the government could do to improve and increase the amount of settlement services and nonprofit organizations that are developing relationships alongside Indigenous organizations and people. 


\section{THEORETICAL APPROACH}

My theoretical framework focuses on decolonization and Indigenous resurgence because I do not believe that we live in a postcolonial country. Within the past two decades little has changed to address the historical warfare on and murder of Indigenous people, and Canada's policies of assimilation (Lowman \& Barker, 2015, p. 3). The warfare and murder of Indigenous peoples refers to the racism, violence, epidemic of missing and murdered Indigenous women, discrimination by social services, brutality in the hands of police and the ability of the state to continue dishonouring treaties and marginalizing Indigenous people (Lowman \& Barker, 2015, p. 3). Wotherspoon and Hansen (2013, p. 29) explain how Indigenous thinkers state that colonialism is not a thing of the past but rather present within Canada's society. Indigenous people are continuously marginalized socially, residential school and policies like the Indian Act made it difficult for Indigenous people to carry on their traditions, culture and identity to the next generations of today and economically, due to lack of infrastructure, inequality in funding for equitable education and the inability of the state to allow them to make decisions for their land. Indigenous people continue to be excluded from national legislation and policy-making decisions. Until they are rightfully involved and employed within these areas, Canada will continue to be a colonial country excluding and making decision on behalf of Indigenous people. Action must be focused around Indigenous life and community; if it is not, the privileged setter society will continue to be the focus.

Residential schools, which were run by the State from 1870s until the 1990s, were designed specifically to remove Indigenous children from their homes and assimilate them into European society (Union of Ontario Indians, 2013). These schools forbade 
children from speaking their Native language, forced them to speak English, wear uniforms, cut their hair, and adopt the religious denomination of the school. If they did not obey these rules they would be physically beaten, sexual abused, electrically shocked, shamed, burned, and/or locked in a closet (Union of Ontario Indians, 2013). These schools provided limited, non-nutritious food, exposed children to illnesses and forced them to work in unsafe environments (Union of Ontario Indians, 2013). Their cultural traditions were villainized. Therefore, I hope my research will support and encourage settlement services to work alongside Indigenous people in regenerating their languages, oral culture, traditions of governance and everything else that residential schools attacked by promoting relationship building between newcomers and Indigenous people through the connection and work of settlement services and Indigenous organizations. If settlement services and non profit organizations developed relationships with Indigenous organizations and people, Indigenous peoples may feel a sense of pride to share their language, culture and traditions with newcomers, which could help to regenerate their culture from centuries of colonization and cultural genocide, starting decolonization and a process of Indigenous resurgence.

Decolonization is first and foremost a process. It is about starting the conversation and furthering the dialogue in order to make a change and begin including Indigenous voices and perspectives into leadership and decision making positions (Sium, Desai \& Ritskes, 2012, p. 2). If spaces for these conversations are not provided then action and change becomes impossible. Simpson (2011, p. 51) explains how decolonization is not only an individual process, but also a collective process that requires collaboration within each community and support from allies. Within my research I was unable to center my 
topic on Indigenous people and their perspectives, so instead I asked settlement services what they are doing to center their work around Indigenous knowledge and perspectives. Altering our action to revolve around Indigenous perspectives allows for a new future to be constructed, different from the one that has been perpetuating for centuries since the European explorers arrived and stole land from the Indigenous population (Sium, Desai \& Ritskes, 2012, p. 12). I want to ensure this Major Research Paper does not simply follow an anti-colonial theory that claims to be against colonial power but yet continues the colonial narrative. Rather, I want to present an opportunity for Canada's national identity presented to newcomers to become a mutually shared identity maintaining alliances between all people; Indigenous, non-Indigenous and newcomers (Lowman \& Barker, 2015, p. 110). To decolonize is to dismantle settler colonialism while building relationships. This process is transformative, constantly shifting, and will alter depending on the needs of Indigenous communities and how individuals and communities go about determining how they fit within this process (Lowman \& Barker, 2015, p. $112 \& 121$ ). Therefore, it will be important for settlement services to address the needs of Indigenous people and what their views and thoughts when developing relationships.

A main component of decolonization is its focus on "resiliency and vibrancy of Indigenous peoples, and re-energizing Indigenous peoples, relationships, practices and protocols" (Lowman \& Barker, 2015, p. 112). My Major Research Paper therefore stresses decolonization by placing Indigenous people at the forefront, so newcomers can learn about them and their resiliency from Canada's horrendous past. Discussing ways that settlement services and nonprofit organizations can build authentic relationships provides the opportunity for organizations and groups of people to build strength within 
Indigenous communities (Lowman \& Barker, 2012, p. 112). In order to start decolonizing settlers need to begin by learning about this land and who it belongs to, and about the histories that go alongside it. Once we have learned and understood these items, we can begin to center Indigenous knowledge and their needs, and put colonial views, practices and tendency to exploit others to the side and behind. Next, as settlers, we need to learn where our time and efforts are welcomed. In this spirit, I analyze Canada's national identity in the context of multiculturalism and how it has excluded Indigenous people, and I examine settlement services and nonprofit organizations that are beginning to work alongside Indigenous organizations and people to change part of Canada's national identity and look into the benefits, challenges and next steps to building relationships between newcomers and Indigenous people. Lastly, we must support Indigenous struggles proactively within our own lives and communities. Decolonization is about a shared responsibility and a focus on collaborative decision-making, which requires conversation, practice and a willingness to unlearn (Walia, 2012; Dymtriw, 2016, p. 14). Therefore, it is important that decolonization is about a new thought process.

The process of unlearning and starting the conversation is an essential step towards decolonizing, although Green (2016), Palmater (2017) and Alfred (2017) explain that truth and knowledge is not enough to decolonize. Alfred (2017, p. 12) states that white settlers have made Indigenous peoples refugees and trespassers in their own homelands and in order to decolonize, material resources need to be returned. Alfred (2017, p. 12) explains that within the Royal Commission on Aboriginal People, ancestors had a unified voice that stated, Indigenous people need to be given back what was stolen, their land and power in decision making over their land and lives, to truly decolonize. 
Currently, Indigenous people have $0.2 \%$ of land on reserves, when they once had $100 \%$ of the land (Manuel, 2017, p. 20). This dispossession of land and forced dependency on the state "is at the heart of the colonial system" (Manuel, 2017, p. 21). To decolonize, dispossession and dependency must be altered through a shift in power and wealth (Palmater, 2017). Green (2016) reinstates Palmater when she explains that "truth is a necessary but insufficient" (p. 2) because decolonization requires a changes in who has power and actions must go beyond telling the truth. Green (2016) also states that truth telling is useless if those who are hearing it are not those who have benefited from colonialism or inflicted the damage. Despite this, she does state that decolonization is possible if reconciliation is enacted well by "contemplating ongoing adaptable relationships with the capacity to carry us all into a positive future" (Green, 2017, p. 13), where restructuring between Indigenous nations and Canada occurs (Coulthard, 2014, p. 168). Within the settlement sector it is unlikely that collaborative work with Indigenous organizations and people will allow for the restitution of land and decision making to Indigenous people, but I do believe that acknowledging the past and present colonization and beginning to share the truth about Indigenous history and knowledge is the first step to moving in the right direction towards decolonization.

Newcomers often come to Canada with little to no knowledge of Indigenous people, in order for them to be a part of decolonization they must begin to learn about Canada's history. They may not necessarily need to unlearn like white settlers have too, as some would not have been subjected to colonial, western worldviews before coming to Canada, but be provided with opportunities to learn accurate information about Indigenous people from Indigenous people. Unfortunately, newcomers are often absorbed 
into mainstream society, which can lead newcomers to adopt the negative stereotypes that are often placed onto Indigenous people by mainstream society. When this is the case, it becomes essential for newcomers to unlearn and be provided with opportunities to interact with Indigenous people personally so they can develop their own perceptions and thoughts based on their own experiences.

In order to start decolonization, Indigenous resurgence is necessary. Resurgence is about reconnecting with the land, culture and communities, hearing diverse perspectives as well as acting against the forces that are working towards assimilating Indigenous people into Canadian society (Corntassel, 2012, p. 97; Simpson, 2011, p. 86). Simpson (2011) explains Indigenous resurgence through a story that is known not only in Nishnaabeg culture but also in the Tlicho region in the Northwest Territories. The story is called Waynabozhoo and the Great Flood. The story is about how Turtle Island was created after the world was flooded as a way to start over after violence and conflict. A large flood was brought to the lands as a restorative measure, but Waynabozhoo managed to survive by floating on a large log. Waynabozhoo allowed other animals to come upon the $\log$ before deciding to dive down into the water to get a handful of earth to start new. Waynabozhoo and several animals attempted to dive deep into the water to bring up a handful of earth with little avail. Then, Zhaashkoonh, the muskrat said it would try, all the other animals mocked and ridiculed Zhaashkoonh thinking it would not be able to succeed. The muskrat dived deep into the water grabbing a handful of earth before resurfacing dead. When Waynabozhoo picked the muskrat out of the water they noticed the handful of mud within Zhaashkoonh's paw. Afterwards, the turtle offered his back to bear the weight of the land. As the wind blew and the animals danced the land began to 
grow and grow. This new land is what we call North America today. Simpson (2011, p. 69) states that the act of diving down for our own handful of earth and transforming it into something new is what we must do for Indigenous resurgence. We must all strive to be like Zhaashkoonh and struggle down to the bottom of the water in order to obtain a handful of earth. Colonization has been detrimental and in order to overcome it, we must each struggle and sacrifice as Zhaashkoonh did. Once we have gathered our dirt it is our responsibility to "ensure our action is collectivized" (Simpson, 2011, p. 69). In this story the turtle offered to carry the weight of the world on her back and the animals danced a new world into existence. Applying this parable to us, people of Canada, to begin Indigenous resurgence we must carry a vision with both individual and collective responsibilities (Simpson, 2011, p. 69).

Waynabozhoo's story explains Indigenous resurgence as an individual process of struggle and transformation as well as a movement towards collective action. In order for Indigenous resurgence to be possible individuals must first struggle to gather the dirt and then collectively work with others in order to create action and start decolonization. This process will not be easy. Simpson (2011) explains that the process involves "sacrifice, persistence, patience and slow, painful movement" (p. 67). Decolonization and Indigenous resurgence both have the power to transform settler society so that an authentic relationship is developed on Indigenous principles of peace, justice and righteousness rather than dispossession, superiority, control and assimilation (Simpson, 2011, p. 66 \& 67). Through my research I hope to contribute to the transformation by exploring how settlement organizations and nonprofit organizations have started this process specifically between newcomers and Indigenous people. 
Another theoretical framework that must be discussed to further heighten points made within my critical literature review is multiculturalism. Multiculturalism is a framework that claims inclusiveness and acceptance of all diversities. Bannerji (2000, p. 8/9) states that society needs to be aware of when this term began to appear in governing discourse and the reasons why the political society were so open to it. It was not until Canada begun to see an influx of third world immigrants into Canada and had the need for these immigrants for economic growth, that multiculturalism began to be embraced. Bannerji (2000) explains that there was a shift from "exclusion and marginalization to ethnic identities and their lack of adaptiveness" (p.9), yet there is little difference between these two movements as "official multicultural ethnicities are from the constructs of colonial- orientalist and racist- discourses" (p. 9). Cleary, multiculturalism was and is used as a tactic for economic growth and a movement from assimilation to integration, rather than the acceptance of different races, classes and genders. Ghoyashi (2010, p. 97) explains that multiculturalism claims to celebrate diversity and encourage different cultures and traditions, but by not addressing the inequalities that are present in Canada it only deepens segregation. Multiculturalism is used as a band aid so that the settler colonial state can hide the deprivation of Indigenous people and present Canada as a good country with no evidence of the state's violent and racist past (Yoshida, 2014, p. 55). Multiculturalism claims it is inclusive, respectful and accepting of everyone when in actuality it is used to serve the settler colonial agenda of keeping white settlers in power, making the decisions and controlling the land. Multiculturalism is a framework of nation building through integration into one unified, mainstream identity (Winter, 2007). 
Therefore, multiculturalism will be analyzed, critiqued and a new national identity will be suggested to include all Canadians; newcomers, Indigenous and others.

In conclusion, my paper is informed by two main theoretical frameworks; decolonization and Indigenous resurgence, in order to present an Indigenous worldview where settlers, newcomers and Indigenous people can challenge the status quo, colonialism, to begin to move towards restitution. The multicultural framework is essential because it presents itself as uniting people, but in actuality divides people because multiculturalism is used as a coping mechanism for conflicting heterogeneity in a homogeneous nation, where only whiteness is truly accepted. Therefore, "the practice is clearly exclusive, not only of third world or non-white ethnic [newcomers], but also of the [Indigenous] population," because they are unable to 'truly' integrate as the nation state requires (Bannerji, 2000, p. 42). Mohawk elder Jake Swamp explains that settlers should not merely copy Mohawk teachings but instead apply the principles to ways we are connected (Lowman \& Barker, 2015, p. 118). Our actions and assumptions affect all of those around us. These theoretical frameworks must be applied in order to begin building authentic relationships that can lead to a new perspectives and worldviews that can begin to place Indigenous knowledge and information at the forefront of decision making.

\section{METHODOLOGY}

My research presents a qualitative study using case studies, literature review and interviews. Collective case studies were used to provide an in-depth understanding about the present examples of settlement services or nonprofit organizations in Canada that have begun to work alongside Indigenous organizations and/or people. There are few 
current examples; therefore, to address the main concern, I will provide thorough information on case studies that are currently available.

First, I conducted a literature review in order to "present and summarize the current state of knowledge" on Indigenous involvement in settlement services (Neuman, 2006, p. 112). This information helped provide the base for my interview questions. I examined scholarly journals, master's theses, dissertations, nonprofit organization publications, books, and periodicals such as news articles, government documents and policy reports. In order for published documents to qualify as useful they had to discuss multiculturalism as a part of Canadians National identity in relation to newcomers and/or Indigenous people, explain how Indigenous people are excluded through Canada's multicultural identity or explain strategies as to how Indigenous Organizations and/or leaders could or have been effectively involved in settlement services to better inform newcomers of Canada's First People. Relevant sources were located by searching various databases, including Google Scholar with the use of the "cited by" feature to provide more useful sources, a general Google search, the "search everything" Ryerson University search engine as well specific database systems such as Politics Collection, Sociological Abstract, Proquest Research Library and Aboriginal Research Portals. Many useful leads were found within the references of scholarly journals and dissertations. The key words or phrases used to search for articles were "Aboriginal perspectives on immigration", "First Nations immigration Canada", "decolonizing immigration", "Indigenous people and multiculturalism", "Newcomers and Multiculturalism", "Indigenous people and Newcomers" as well as "Indigenous perceptions of Newcomers" and "Newcomers perceptions of Indigenous people". I substituted the term Indigenous 
people with First Nation, Native people or Aboriginals in order to expand my search. I followed the same process for the term newcomer, and substituted the word with immigrants or migrants. I identified several case studies where settlement services/nonprofit organizations collaborated with Indigenous people or organizations. The case studies were chosen based on three inclusion criteria: organizations within Canada; settlement services or nonprofit organization serving newcomers or an Indigenous organization and a present existence or start on providing information, workshops and/or programs for newcomers and Indigenous people. Even if these organizations did not have current programs or relationships in place with Indigenous Organizations they were still deemed useful for my interviews because they could still present what relationships and programs they hoped to engage with in the future and why. The case studies were researched before the interviews took place to gather background information and to find out whether they currently provided programs that dealt with newcomers and Indigenous people in order to further my interview questions.

I was unable to obtain interviews with Independent Indigenous Organizations therefore, my interviews were conducted with key stakeholders from settlement service agencies and nonprofit organizations. These groups were targeted based on the information that was provided from their online website, which presented them as moving towards or already starting the process of building relationships between Indigenous people and newcomers. My request for interviews was conducted mainly through email but also through phone calls. I ensured interviewees did not feel coerced into participating by allowing time for their decision after the first email was sent out. Organizations were given a week after the first email before a second email was sent to 
remind and ask them for a confirmation on whether they were interested in participating or not. If no response was received after the second email no other form of communication, emails or phone calls, were made to ensure the organizations did not feel coerced into participating. Furthermore, creating a consent form, which informed them that their identification would not be mentioned in the research output, protected the identities of the interviewees. Instead of using the interviewees' names each interviewee was given a pseudonym. The audio recorded interviews; transcripts and consent forms were stored separately from each other.

The interviews took place in a location of the interviewee's choice to ensure they were comfortable and at ease when answering questions. All interviewees chose their location of work or a phone call for the interview. The interviews were completed using semi-structured interviews in order to address settlement services/nonprofit organizations involvement with Indigenous organizations and people (Neuman, 2006). The interview questions focused on the extent and nature of their involvement with Indigenous organizations and people, the benefits of creating information, workshops and/or programs to build Indigenous and newcomer relationships, the challenges and preventions to building these relationships as well as how they foresaw their organization moving forward in the future. If the organization had yet to collaborate with an Indigenous organization, I would ask about their expectations and foreseeable benefits and challenges. Specific questions used during the interviews are outlined in the Appendix. Several organizations were contacted for interviews but in the end KAIROS Canadian Ecumenical Justice Initiatives, a nonprofit organization working with newcomers and Indigenous people; OCASI, Ontario Council of Agencies Serving 
Immigrants; COSTI, settlement service agency in Toronto; Vancouver Dialogue Project, pilot project for newcomers and Indigenous people; and Canadian Roots Exchange, programming for Indigenous and non-Indigenous youth were the organizations who participated. Each interview took between 30 and 60 minutes; the process of emailing, booking interview times, and conducting and transcribing the interviews took between 56 weeks to complete. Unfortunately, I was unable to obtain any Indigenous organizations or people to interview for my research. I believe this only reiterates how Indigenous people often see few benefits from the research that involves them. I, and other allies, need to begin building this relationship of trust, patience and respect in order to collectively work alongside Indigenous people to make change.

\section{CRITICAL ANALYSIS OF THE LITERATURE}

This critical analysis of the literature will explain how an integral part of Canada's national identity - multiculturalism - continues to marginalize or exclude Indigenous people, continuing the colonial cycle. Within multiculturalism, Indigenous people are not acknowledged or even represented as the First people of Canada, which forces newcomers to be placed within settler colonialism. I will propose that Indigenous people should not be inserted or absorbed within Canada's national identity but rather Canada's national identity should change to instead represent and acknowledge all identities, especially Indigenous people, in a way that allows non-Indigenous people, newcomers and Indigenous people to collaborate. After explaining how Canada's national identity excludes Indigenous people, I will make suggestions on how relationships can be built between Indigenous people and newcomers. Lastly, I will recommend an alternative to 
Canada's national identity that could place Indigenous people as the main welcomers of Canada.

Multiculturalism, as an important piece of Canada's national identity, serves the settler colonial agenda by convincing Canadian citizens that Canada has equality and integrates immigrants better than any other country in the world (Lowman \& Barker, 2015, p. 73; Kymlicka 1988, 21). Canada is a state founded on stolen land that hides its racism, violence and denial, sells diversity and favors the dominant groups, French and English (Lowman \& Barker, 2015, p. 77; Abu-Laban \& Gabriel 2002). The "we" in Canada does not mean Indigenous people or newcomers, it means those who are white. Those who are "outside of this moral and cultural whiteness are targets for either assimilation or toleration" (Bannerji, 2000, p. 42). Multiculturalism is a form of toleration, as it is used as a political and administrative framework that lessens the discussion on structural inequalities (Bannerji, 2000, p. 45). Multiculturalism as an ideology can be used to cover up the injustices that happen currently and frequently within Canada for newcomers and Indigenous people. As Bannerji (2000) states multiculturalism emerges, instead of from a place of inclusivity, "as a device and a legitimation for a highly particularized ideological form of domination" (p. 105). This domination is the same power and control that attempted to eradicate all Indigenous people in the past through genocide. Canada has yet to address colonization and the continued marginalization of Indigenous people, although it seeks to be a liberal democratic state through the use of multiculturalism, that only continues to separate white settlers and newcomers, us vs. them. 
Multiculturalism, as an ideology, continues to exclude Indigenous people through historical acts and policies from the past, by continuing the colonial system, which integrates newcomers through settlement services, through the current citizenship guide (Discover Canada) and by forcibly dividing newcomers and Indigenous peoples, which helps to reinstate newcomers negative perceptions of Indigenous people and Indigenous peoples negative stereotypes of newcomers. Newcomers are integrated into multiculturalism, which actively excludes Indigenous people, keeping both newcomers and Indigenous people separated. When these groups of people are kept divided the negative perceptions that exist about each other are continued and not questioned through interactions. As a consequence, Indigenous voices, knowledge and history tend to be excluded from settlement services that welcome and integrate newcomers into Canada.

In the past, the main goal of the government was to assimilate or exclude Indigenous people. This goal continues today through the discourse of multiculturalism because other cultures other than white settlers present in Canada are seen as a threat to the national culture. Therefore, multiculturalism was and is still used as a coping mechanism for dealing with the conflicting heterogeneity that the state wants to incorporate into the two solitudes, either French or English, to create a homogeneous nation (Bannerji, 2000, p. 42). First, the federal government created residential schools in 1870, where Indigenous children were forcibly removed from their homes to attend industrial schools (Rheault, 2011). These schools were designed to assimilate Indigenous people or "kill the Indian in the child," by forcibly removing their culture and tradition in horrendous ways (Rheault, 2011). These schools perpetuated white supremacy, as being native was deemed unacceptable. During the Gradual Civilization Act of 1857 and 
Enfranchisement Act of 1869, white legislators thought that Indigenous people would give up their native identity and relinquish their treaty rights in order to obtain privilege and Canadian citizenship (Voyageur \& Calliou, 2001, p. 110). When this did not occur their status would forcibly be removed and they would gain citizenship if they became literate, were educated, and/or had an acceptable moral character (Voyageur \& Calliou, 2001, p. 110). Indigenous people were not even considered citizens of this country unless they assimilated to Western, mainstream society.

Today, although Indigenous people can obtain citizenship and Indian status they are displaced from mainstream society due to the Canadian state's past actions. The Indian Act, created in 1876 and amended in 1951, is still in place today and used to control and "civilize" Indigenous people (Voyageur \& Calliou, 2001, p. 105). The federal government tried to introduce the White Paper in 1969, which aimed to remove Indian status and make Indigenous people the same as every Canadian, and, yet again, assimilate them. Indigenous people strongly refused the White Paper because if all Indigenous people were given citizenship their Indian status would be removed and treaties would be abolished (Macdonald, 2014, p. 74). The White Paper was a direct attack on Indigenous identity, rights and traditional lands. Many Indigenous people claim that multiculturalism is similar to the White Paper, as they both attempt to forcibly place Indigenous people within mainstream society by trying to frame them as any other minority group (Macdonald, 2014, p. 75). White settlers are the only ones whose imagination is advanced in the national imaginary, which is multiculturalism; therefore, all others are not apart of the self-definition of Canada. Instead, newcomers and Indigenous people are given labels to identity themselves such as visible minorities and/or others, which are 
created in the ideology of the nation, multiculturalism (Bannerji, 2000, p. 65). Each aspect of Canada's history towards Indigenous people shows time and time again how the Canadian state continues to be willfully ignorant. Each event or action of the past, mentioned above, serves the interests of newcomer Canadians and settlers at the expense of Indigenous people and at the expense of an inclusive Canadian society (Godlewska, Moore \& Bednasek, 2010, p. 419). Clearly, this willful ignorance is still prevalent and ongoing, proving that part of Canada's national identity linked to multiculturalism that attempts to be inclusive, is in fact exclusive to Indigenous people.

Winter (2007, p. 39) and Bauder (2011, p. 517) explain how multiculturalism is the framework for nation building and immigrant integration." $[\mathrm{I}] \mathrm{t}$ is a continuation of white supremacy and colonialism" (Winter, 2007, p. 39) by bringing people into Canada for economic benefits and by integrating them into Canada's white, western mainstream society (Bannerji 2000). When newcomers come to Canada they are forcibly placed into the fabric of the nation that has no place for Indigenous people (Macdonald, 2014, p. 71). Therefore, newcomers, whether racialized or marginalized (or both), become citizens and enter into a relationship with the state, which in turn makes them settlers (Stanley, AratKoc, Bertram \& King, 2014). An example that showcases how newcomers, often unwillingly, are integrated into Canada as settlers, continuing the colonial cycle, is the citizenship guide, Discover Canada. Yoshida (2014) explains how the citizenship guidebook and test are "settler making tools" (p. 8) used to sustain the colonial structure. The 68 page long guidebook mentions Indigenous 62 times in the context of history or in relation to different categories of Aboriginal people (Chung, 2014, p. 30). Present day issues of Indigenous people are non-existent within this guidebook. Even though the 
guidebook does mention Stephen Harper's apology for residential schools, this reference overlooks the colonial oppression that still exists. Yoshida (2014, p.62) explains that the sentence, "In today's Canada, Aboriginal peoples enjoy renewed pride and confidence" (p. 61) implies that exploitation and colonialism of Indigenous people is a thing of the past, when it is not. The guidebook continues to perpetuate settler colonialism by silencing Canada's colonial past, which continues to de-indigenize Indigenous people without acknowledging the inequality and oppression that Indigenous people continue to face today. Additionally, Discover Canada explains multiculturalism as a Canadian trait that is the glue that holds this nation together (Yoshida, 2014, p. 90). Discover Canada is a citizenship guidebook designed by the government for the purpose of integrating newcomers, with the insinuation that Indigenous people are excluded from Canadian identity. When newcomers must read this book to become Canadian citizens they are asked to be absorbed into the "collective body of "Canadians"” (Yoshida, 2014, p. 23), that has no place for Indigenous people.

The citizenship guidebook and test are not the only forms of Indigenous exclusion within Canada's national identity, as immigration policies and multiculturalism are designed specifically for settlers and newcomers, not for Indigenous people. Immigration policies throughout time continue to exclude Indigenous people from the decision making for and the fate of their land. Immigration policies related to the land are often made by those who directly oppose Indigenous peoples' interests. For example, the 1910 Immigration Act makes no reference to protecting the land nor does it even place Indigenous people within the history of Canada; instead it is based on the interests of Europeans settlers as the governors of the country (Dymtriw, 2016, p. 39). The absence 
of consulting and/or involving Indigenous people in the decision making process in regards to policies involving their land continues in the 2002 Immigration and Refugee Protection Act (Kasparian, 2012, p. 1). The continuation of Indigenous oppression is only perpetuated through the goals of multiculturalism. The four main goals for multiculturalism are:

(1) To support the cultural development of ethno-cultural groups;

(2) To help members of ethno-cultural groups overcome barriers to full participation in Canadian society;

(3) To promote creative encounters and interchange among all ethno-cultural groups;

(4) And to assist new Canadians in acquiring at least one of Canada's official languages. (Voyageur, Colliou, 2001, p. 103)

It is clear through these goals that the main purpose of multiculturalism is to integrate newcomers into Canada's mainstream society, which forcibly excludes and ignores Indigenous people and perpetuates the colonial cycle.

The Truth and Reconciliation Commission (2015) notices this goal and the need for change as it created two calls to action that specifically pertain to the information newcomers obtain. The citizenship guide and test relates to multiculturalism because they are used as a settler tool that provides limited information about Indigenous people and perpetuates colonialism. The citizenship guide and test are used to absorb newcomers into Canada's mainstream society. Among the Truth and Reconciliation Commission calls to action is number 93, which calls for change in the information kit and citizenship test so that they contain a more inclusive history of Indigenous people and Canada's history; as well as Action 94, which calls to include treaties within the citizenship oath ceremony (TRC, 2015, p. 10). These two, as well as many other, calls to action have yet to be addressed. 
The Canadian state has attempted to define Indigenous people as "visible minorities" but this strategy only further explains how Indigenous people continue to be unrecognized as the First People of Canada and how the state continuously tries to integrate them into mainstream society along with newcomers (Winter, 2007, p. 46). Settlement services across Canada, due to funding and lack of knowledge, focus on integrating newcomers with little to no mention of Indigenous people whose land they will be living on. By integrating newcomers, policies seek to place them within a singular identity of Canada: the "discourse of multiculturalism... undermines the autonomy of Indigenous communities by granting and mediating rights through the imposed structures of the state and...seeks to assimilate diversities into a singular Canadian identity" (Walia, 2012, par. 15). Unfortunately, a large share of settlement services' funding comes from the federal and provincial governments, which means that if Indigenous knowledge and history are not made a priority by these governments, then little to no funding is given to develop programming incorporating Indigenous knowledge, history or perspectives. Current policies towards newcomers sustain the European settler colonial identity, rather than supporting Indigenous people's goals and culture (Dymtriw, 2016, p. 44). In order to change this part of Canada's national identity and programming in settlement services, government policy must ensure that Indigenous people and their knowledge are recognized, acknowledged and given priority. The only way to bring Indigenous rights and goals to the forefront, especially within settlement services, is to move away from integrating newcomers into the colonial structure and instead oppose it by involving Indigenous people and their knowledge in settlement services so they can become the welcomers of Canada. 
When settlement services are forced to focus on integrating newcomers into Canada's multicultural identity, they continue to divide Indigenous people and newcomers. The states organization of race and ethnic terms constantly creates "Canadians" and "others" (Bannerji, 2000). Newcomers are often placed with the category of "others," while Indigenous people are merely unacknowledged or placed alongside newcomers, in the "others" category, when they are anything but new to this country. This division leads to the continuation of negative perceptions and stereotypes of each other. Sykes and Kunz (2007, p. 9) explain that multiculturalism tends to do the opposite of uniting Canadians, as it tends to divide people based on power and skin tone because "multiculturalism is a vehicle for racialization" as anglo-Canadians (whites) are the ethnic core culture while all others are being "tolerated" and classified around the core culture, which is said to be multicultural (Bannerji, 2000, p. 78). Chung (2012) asserts that the one damaging effect of multiculturalism is the "strict separation between Indigenous people and immigrants" (p. 51). Bannjeri (2000, p. 79) explains that multiculturalism only accepts culture and ethnicity at a surface level such as ethnic food, clothes, songs and dance, while refusing demands that go deeper such as funding for “others" arts and cultures. This example clearly states how Indigenous people and newcomers are separated through multiculturalism, as the ideology accepts newcomers different cultures and ethnicities at a surface level while Indigenous culture is not accepted at a surface level nor at a deeper level, they are simply ignored and unacknowledged. Bannerji (2000) reinstates this when she says, "the issues of First Nations- their land claims, so violent and deep that the state of Canada dare not even name it in the placid language of multiculturalism" (p. 97). Indigenous people and 
newcomers tend to have some similarities that, if discussed, would help them become allies. The discourse of multiculturalism, however, actively drives Indigenous people and newcomers apart. Even though many newcomers are marginalized and oppressed themselves in Canada, they will still identify with the Settler Canadian narrative because in order to obtain employment, citizenship and other benefits they must integrate and absorb the mainstream Canadian identity (Lowman \& Barker, 2015, p.44). In Ghorayshi's (2010) study, interviewees explained how “racism, misinformation, isolation and lack of interconnectedness" (p. 91) between newcomers and Indigenous people is a problem that surpasses housing and employment. The negative perceptions between Indigenous people and newcomers are due to the lack of dialogue that exists between these two groups.

It is also important to remember that newcomers and Indigenous people are both highly diverse groups with a wide range of viewpoints and experiences. Research based on interviews has found that Indigenous people often view newcomers as new colonial settlers who are arriving and living on stolen land. Therefore, Indigenous people often perceive newcomers as people who are only continuing the colonial project (Walia, 2012). Another ongoing issue that seeps into Indigenous perceptions of newcomers is in relation to scarce resources such as jobs and subsidized housing (Kasparian, 2012, p. 6; Gooder, 2017, p. 41). As Cheadle (2012) shows, many Indigenous people feel that Newcomers are stealing opportunities for employment and that Canada should focus on helping its own people first before bringing more here. In the Canadian Press, Cheadle (2012) mentions how Betty Ann Lavallee, the National Chief of the Congress of Aboriginal Peoples, states, "Canada needs to train and employ aboriginal youth, not bring 
in foreign help" (para. 14). Similarly, the Batchewana First Nation Chief, Dean Sayers, stated, "Don't be bringing 200,000 more foreigners into these lands if you can't even look after the responsibilities you have to us already" (Cheadle, 2012, par. 20).

Newcomers to Canada often have few opportunities to pursue conversations with Indigenous people. Subsequently, negative stereotypes tend to take root among newcomers (Suleman, 2011, p. 8). The harm placed on Indigenous people by colonialism is often reframed by settler Canadians as being due to Indigenous people's harmful behavior, laziness, or willful backwardness that is to blame for the present day "Indian problem" (Lowman \& Barker, 2015, p. 88). Newcomers often adopt this mindset and believe that there is in fact an "Indian problem." Many newcomers arrive to Canada with little to no knowledge on the Indigenous people of Canada, which often allows them to easily believe and reinforce the negative stereotypes that settler Canadians and the media present. Ghorayshi (2010) states, "the colonial, stigmatized, and stereotyped view of Aboriginal people is transferred to the newcomers" (p. 95), leading newcomers to believe that Indigenous people are lazy, not paying taxes, have a drug or alcohol problem and/or are dependent on welfare (Chung, 2012, p. 31). Despite that fact that Indigenous people and newcomers often live in close proximity to each other they also often live in social isolation from each other. Gyepi-Garbrah, Walker and Garcea (2014) corroborate this view through their interviews with newcomers and Indigenous people within the inner city of Winnipeg. One newcomer stated:

The first time I came to Winnipeg, the few people who I met....who are drunk outside, begging for money and all the time I was wondering, man, I was coming to Canada, life is golden. How come these people are begging? How come these people are drunk all the time and for a while my perception of [the] Aboriginal community was defined by that group that I 
met....(male adult newcomers, mixed focus group-talking circle). (p. 1804)

This is one of the many examples of how newcomers often perceive Indigenous people in Canada. Shady Hafez, a Carleton University student whose mother is Algonquin and father is Syrian, stated, "on the immigrant side, Canada was savior. And on the other side, it was a destructive force" (Laucius, 2015, par. 14). Most newcomers see Canada in a positive light before realizing the damage it inflicted on Indigenous people. When the state is seen as a savior and mainstream society presents Indigenous people "as abusive, lazy alcoholics whose lack of political, social and economic power is self inflicted" (p. 147) it reinforces the divide and negative perceptions newcomers have of Indigenous people (Khan, Alan, Pennington \& Richardson, 2015). To remove these negative perceptions and to build relationships between Indigenous people and newcomers, it is crucial that settlement services and Indigenous organizations work together. Gooder (2017, p. 57) explains that facts are rarely enough to change the views of people; it is personal connections that can be created through programming and activities that provide space for dialogue, which will make the difference in how newcomers and Indigenous people view each other.

The two fastest growing Canadian communities, who also have inadequate access to social and economic resources, such as housing and employment, are newcomers and Indigenous communities (Khan, Alan, Pennington \& Richardson, 2015, p. 151). Dialogue between these groups could address a "fair and equitable future in Canada" (p. 151). When newcomers and Indigenous people start conversations it opens up space for critique and resistance against colonialism. Dialogue can create a transformation from a dominant/subordinate social structure into a new structure based on common relations 
(Sharma \& Wright, 2008/09, p. 127). When newcomers and Indigenous people begin to share their stories and experiences they often realize a "common struggle against [expropriation and exploitation] processes and against identities of race, nation and gender (Sharma \& Wright, 2008/09, p. 132). Rather than being against each other, these dialogues allow different groups of people to find a commonality that links them in the struggle against colonialism. Conversations can allow for a rethinking of our relations to one another and to space (Sharma \& Wright, 2008/09, p. 131). Therefore, once dialogue begins a shared experience of exclusion, colonialism, racism, prejudice, and the desire to protect their culture may become apparent, they can lead to building positive and productive relationships (Gyepi-Garbrah, 2010; Khan, Alan, Pennington \& Richardsons, 2015, p. 149). Kasparian (2012, p. 5), Gooder (2017, p. 25), the Truth and Reconciliation Commission (2015, p. 354) and Chung (2012, p. 53) all agree that dialogue is essential in creating these relationships and removing the division that multiculturalism often places between these two groups of people. Kasparian (2012) states, "it is through dialogue that we will be able to forge ties, educate people, raise awareness, redefine the terms immigrant and Aboriginal, rehabilitate the past, come to terms with the country's history and finally feel at home in Canada" (p.7). In order to create authentic relationships, space needs to be provided, which will provide opportunities for dialogues to occur between Indigenous people and newcomers.

The following examples illustrate how important dialogue is for Indigenous people and newcomers to build healthy relationships. Basel Alrashdan, a 13-year-old Syrian refugee began to talk to Charlotte Morris, a Mi-Kmaq grandmother who survived a residential school, for his heritage fair project (Tremonti, 2018). They connected 
because they were both taken from their homes but in very different ways. Basel in a CBC segment states "it's very interesting and very important to know, all people should know about what happened to Indigenous people" (Tremonti, 2018). He goes on to explain how he was welcomed with warmth and respect when he arrived to PEI and he was saddened to hear that this was not the case for Charlotte, as she was taken from her family and deprived of her culture. Charlotte explains in the interview that she feels she has a life long friend after meeting and speaking to Basel. The conversation between Basel and Charlotte is not only impactful for the two involved but for all those who listened to the segment as well, as Basel explains that when he gets his citizenship he hopes to recognize the treaties in Canada that he will subsequently become a part of.

A second example of the importance of dialogue between Indigenous people and newcomers can be seen when Pakistani Canadian Sadia Rafiquddin and Innu elder Elizabeth Penashue shared a conversation and a cross cultural experience during Elizabeth's $250 \mathrm{~km}$ walk from Labrador to her birthplace inside Mealy Mountains, which Sadia joined her on. Rafiquddin (2017) explains her experience:

over 250 kilometers, she and I and her family shared so much. We talked about our languages, our communities, where we came from, what the experience of being forcibly removed from one's homeland has on a sense of well-being for a person. She says it's important to make such a connection because coming together will ultimately make Canada a better country. We need to hear about our common humanity. We need to be less us versus them and think more about all of us being together and building a better country. (par. $8 \& 9$ )

Between these two examples it is clear that dialogue is essential to creating change. On an individual level it opens up opportunities for authentic experiences and relationships as well as newfound respect for each other. On a federal level, the government needs to realize how important it is for settlement services to build relationships with Indigenous 
organizations and people to allow opportunities for these conversations to occur, so newcomers are learning about the First People of Canada.

Alongside dialogue between Indigenous people and newcomers, cross-cultural activities need to be developed. Cross-cultural activities allow both groups to experience each other's culture and to better understand and receive accurate information from each other. These experiences allow them to recognize that they share a lot in common, how to value their differences, and how to understand the problems that each other face (GyepiGarbrah, 2010). As will be explored in my case studies below, these types of activities or programs help Indigenous people and newcomers to appreciate their differences, by allowing newcomers to be reliably informed about the first inhabitants of Canada (GyepiGarbrah, 2010).

Indigenous people are not responsible to teach settlers about decolonization, it is the state's responsibility to eliminate the division that is created and sustained through Canada's multicultural identity. If the state does not address institutional racism and privileges people have within the nation then these structures will only continue to exclude others, the possibility for true inclusion will not be successful (Gooder, 2017, p. 17). Instead of using multiculturalism, the state needs to begin by placing Indigenous people at the forefront so they can become the welcomers of Canada, this could be addressed through treaties. Treaties are nation-to-nation agreements based on respect and peace. Currently, there are over 300 treaties across Canada, unfortunately the majority of these treaties are not being upheld by the government of Canada (KAIROS, 2018). The government should emphasize and acknowledge these treaties that newcomers immigrate onto, as a large majority of Canada is on treaty land, therefore the people on that land are 
treaty people, unfortunately many people are unaware of this. The state needs to ensure that all Canadians, including newcomers, are recognizing these treaties and the responsibilities that are required of them through these treaties. Settlement services and nonprofit organizations should be required to inform newcomers of these treaties and the responsibilities that are associated with them. Treaties in Indigenous cultures symbolize sacred relationships through agreements between humans and the environment (Simpson, 2011, p. 109). They represent an inclusive circle that expands and gradually adapts as new people join (Khan, Alan, Pennington \& Richardson, 2015, p. 147).

Within Southern Ontario, Wampum Belts were exchanged to represent the record of agreement, which communicates the promises exchanged (Borrows, 1997). Two treaties within Southern Ontario that I will use to demonstrate the significance and symbolism behind treaties are the Dish with One Spoon and the Two Row Wampum Belt. The Dish with One Spoon is a treaty made originally between the Anishinaabe, Mississaugas and Haudenosaunee in relation to the St. Lawrence lowlands and Great Lakes Basin of North America in order to symbolize the importance of sharing the territory and protecting the land (Simpson, 2011). The treaty is designed to ensure that there are enough resources for all and to ensure that the land is taken care of so it can continue to be used by the next generations. All Indigenous, European settlers and newcomers have been invited into this treaty as of 1765 after the French and Indian War had ended, in the spirit of peace, friendship and respect (Kang, 2017). This treaty symbolizes peaceful collaboration between all Canadians living in this region. The Dish with One Spoon Wampum is covered in white to represent peace, unity, and harmony; in the center are purple wampum's in the shape of a bowl. There is only one dish filled with 
beaver meat, which is used to represent the responsibility of the people to ensure that the dish is never empty and that there is always food for everyone to have and share (Simpson, 2011, p. 112). There is to be no knife near the dish to ensure that no one will get cut and cause bloodshed, this symbolizes non-violence. Instead there will be a wooden spoon, which will be shared. This treaty exemplifies how important it is to share the land in a respectful and responsible way. By including not only Indigenous people, but everyone living in the region, it symbolizes equality and respect amongst all.

The Two Row Wampum, otherwise known as Guswenta, and later recognized as the Silver Covenant Chain of Friendship, is one of the oldest treaty relationships between the original people of Turtle Island (North America) and European immigrants (Keefer, 2014). This treaty was embodied in the $17^{\text {th }}$ century between the Haudenosaunee and the Dutch, as the Dutch settlers began to move up the Hudson River into Mohawk territory (Keefe, 2014). This treaty was created to show that both Indigenous peoples and Europeans were equal because when the Dutch first arrived they stated that the settlers shall be called "father" and the Haudenosaunee "son." However, the Haudenosaunee opposed and said: "we shall address each other as 'Brothers", to create an equal partnership (Onondaga Nation, 2018). This treaty was made to show how they were to treat each other and live together. The treaty was extended not only to the Dutch but also with the French, British and Americans under the Silver Covenant Chain agreement (Keefer, 2014). The Wampum belt was created by Indigenous people to record this agreement and to reflect their understanding of the Treaty of Niagara and the words of the Royal Proclamation at the Niagara gathering, known as the Peace Council, in 1764 to create nation-to-nation relationship between settlers and Indigenous people (Borrow, 
1997). At the gathering, over two thousand chiefs attended the negotiations alongside twenty-four Nations. The Two Row Wampum belt symbolizes two paths, two rows of purple represent these paths; one is for a birch bark canoe for Indigenous laws, customs and ways, the other is for a ship to represent European settlers laws, customs and ways. The two rows travelling side by side symbolize how they will each travel the river side by side in their own boats so that neither will try to steer each other's vessel. In between the two rows are three beads of wampum, they symbolize peace, friendship and respect (Borrows, 1997). Therefore, the Two Row Wampum belt symbolizes the relationship between the Haudenosaunee and settlers on this land and specifies that land should not be owned, as it is in the Western, colonial sense, but rather that people should belong to the land as a part of creation in order to ensure it is protected on behalf of future generations. This treaty is a framework for decolonization across Turtle Island as it represents respect for all people and their own systems of self-governance, organization and economy (Keefe, 2014). The Canadian state has failed to uphold this treaty, and many other treaties across Canada, but that does not mean we cannot start the decolonization process now and begin to place these treaties at the forefront, so Canada's national identity does in fact develop in a direction respecting all different customs, laws and ways. This treaty shows diversity and respect in its truest form, as all individuals would be able to maintain their cultural identity.

The key principles to treaties are respect, wisdom, sharing, community, preservation, environment, peace and protection (Kang, 2017). These principles are applicable to everyone living on the land encompassing Canada and those who live on treaty land, whether European settlers, newcomers or Indigenous, are, in fact, treaty 
people. By focusing on treaties, the Canadian state would not simply be placing Indigenous people in a position of domination over white settlers, swapping spots, but rather breaking the existing hierarchical order of society (Memmi, 1991; Tuck \& Yang, 2012, p. 31). By placing Canada's identity around treaties rather than multiculturalism, newcomers will not only be respected for their beliefs and customs, but also become informed about the treaties that shape Canada (Dhamoon, 2015). Indigenous people will once again be the welcomers of this land like they were in the past when they helped settlers survive through their generosity, knowledge and skills (Lowman \& Barker, 2015, p. 35). When Indigenous people become welcomers of Canada and are placed at the forefront of Canada's national identity, Indigenous people, newcomers and European settlers will begin to have a vision of a land, where there is hospitality, sharing, and respect for all living things (Kasparian, 2012, p. 3). "Indigenous knowledge systems have been undermined and devalued during colonization" (Wotherspoon \& Hansen, 2013, p. 28). Now it is time to start bringing about change. Re-engaging with treaties from the past will help orient newcomers to Canada in ways that generate understanding and respect for the struggles and aspirations of Indigenous people (Gyepi-Garbrah, 2010, p. 9). It is important to remember that we have a long way to go to truly decolonize and reconcile. As the Truth and Reconciliation Commission (2015) states: "we are all in this together" (p. 335). We are all responsible for educating ourselves and others about what happened in Canada and for creating positive change that will unit rather than divide us.

\section{CASE STUDIES}

Organizations across Canada are beginning to realize the significance of bridging Indigenous organizations and newcomer organizations, including those that deliver 
settlement services. This section will examine the extent and nature of the work of six different organizations that are currently helping to establish relations between Indigenous people and newcomers. In addition, these case studies highlight the benefits, challenges and next steps to collaborating with Indigenous organizations. The first case study did not involve an interview but was rather based on a review of the literature and available online sources of information on the independent Indigenous organization in Winnipeg, Ka Ni Kanichihk. The other case studies are on the Vancouver Dialogues Project, KAIROS, Canadian Roots Exchange, COSTI and OCASI, and were based on interviews to further understand the extent and nature of Indigenous organizations involvement in newcomer organizations or settlement services. The nature of the organization will be first described before identification of common themes in relation to benefits, challenges and next steps.

\section{Ka Ni Kanichihk (KNK):}

The independent Indigenous organization, Ka Ni Kanichihk (KNK), meaning those who lead, is located in the inner city of Winnipeg. KNK provides a culturally safe environment that builds on the strength and resilience of Indigenous people (KNK, 2017). They focus on bringing a vision to action throughout their 11 various programs that address topics such as the HIV crisis, employment assistance and mentorship, sense of belonging, Medicine Bear counselling and elder services program and much more (KNK, 2017). Two current programs are the Butterfly Club and Root Connection. The Butterfly club is a program designed for 9-13 year old girls and two spirited youth to help develop self confidence and a sense of belonging through community involvement, self development, environmental stewardship and indigenous cultural reclamation (KNK, 
2017). Another KNK led program is Root Connections, a three year culturally based mentorship project for 45 Indigenous female youth, aged 12-17 who are involved with youth street gangs and in the criminal justice system in Winnipeg (KNK, 2017).

In 2010, KNK started to cooperate with community settlement services, so that newcomers and Indigenous people could begin to have conversations and develop connections. They began to focus on Indigenous awareness among newcomers and cultural exchanges between Indigenous people and newcomers (Gyepi-Garbrah, Walker \& Garcea, 2014). The KNK delivers Aboriginal Awareness workshops, Youth Peace building Gathering Programs and anti-racism training to provide cross-cultural relations. The Aboriginal Awareness workshop is provided once a month to newcomers during orientation as a way to introduce them to Indigenous history and culture (Gyepi-Garbrah, Walker \& Garcea, 2014). This workshop allows newcomers to become knowledgeable about the land they are living on and rectify any perceptions they may have about Indigenous people. The Youth Peace Building Program is a weeklong summer camp that allows Indigenous youth and newcomer youth aged 13-16 to come together and talk about themselves and their culture, as well as provide space for them to have fun and get to know each other. Many of the children who participated in this summer camp found they developed confidence and pride in their culture, developed lasting friendships, and that their opinions of certain cultures and people changed (Gyepi-Garbrah, Walker \& Garcea, 2014). These programs are designed to create space for relationships to build between Indigenous people and newcomers, to articulate Indigenous rights and knowledges as well as to take steps forward towards decolonizing the city (GyepiGarbrah, Walker, \& Garcea, 2014, p. 1796). 
Vancouver Dialogue Project:

The Vancouver Dialogue Project was developed in 2010 as a pilot project to bridge the gap between Vancouver's Indigenous and newcomer communities and to create a welcoming and inclusive city for all. The Government of Canada and the province of British Columbia were the key funders for this project while the Social Planning Division collaborated with 27 community partners to create and conduct the initiatives (Suleman, 2011). The program was developed from the new programming called Welcoming Inclusive Community and workplaces. Within this program five main initiatives were created for phase one of the project: dialogue circles, community research, cultural exchange visits, a youth and elders program and a legacy project (Wong \& Fong, 2012).

There were nine dialogue circles where Indigenous people and newcomers met three times a week to share their stories, experiences and perspectives on remembering the past, reflecting on current issues and envisioning strategies to build for future relationships (Wong \& Fong, 2012). They met at various locations in Vancouver that reflected the broad range of community members. For many participants, these Dialogue Circles were the first time they had ever tried to understand each other. Within this process, trust and respect were developed between participants. The main themes that emerged through dialogue were: seeking to understand each other's history and knowledge; racism, as it affected all participants; learning, as each dialogue emphasized how they were learning about each other; land and belonging (for Indigenous people it was the pain from the loss of their traditional land and for newcomers it was the land they left behind); and reconciliation and identity (Suleman, 2011). These conversations are 
essential because, as one participant stated, you can learn about Indigenous history in university but when you actually talk and work with people, you learn things you never knew before (Suleman, 2011). Developing these dialogue circles allowed for many rich conversations that most likely would not have taken place if it was not for the safe and comfortable space provided.

The community research completed by the Vancouver Dialogue Project consisted of a literature review on the amount of Indigenous information available to newcomers. The literature review found limited information about Indigenous people and the information that was available lacked language accessibility and was often not from an Indigenous perspective (Suleman, 2011). Due to the lack of information, the Vancouver Dialogue Project suggested that the government should add more information from an Indigenous perspective into their newcomer orientation package (Wong \& Fong, 2012). This research guided the City of Vancouver to create a Newcomer's Guide focused specifically on Indigenous people during phase two of the Dialogue Project. The guide covers a range of topics including urban Indigenous people, residential schools, the Dialogue Project, and Truth and Reconciliation (Suleman, 2011). This research is essential because it showcases the gaps present within Indigenous and newcomer communities that need to be addressed to create better social cohesion in Vancouver.

Alongside the literature review an online community survey was conducted by the City of Vancouver, close to 500 people participated, with $80 \%$ being non-Indigenous, $64 \%$ were born in Canada, and most respondents were between the ages of 31-64, to gather perspectives. Within the results only $39 \%$ of respondents felt that Vancouver was welcoming towards Indigenous people while $73 \%$ felt Vancouver was welcoming 
towards newcomers (Suleman, 2011, p. 20). Most non-Indigenous participants also felt that newcomer communities did not have a good understanding of Indigenous peoples issues. These findings demonstrate the need for Aboriginal voices, knowledge and history to be better incorporated into Canada's settlement services (Suleman, 2011).

As part of the community research section of the Vancouver Dialogue Project, long one-on-one interviews were conducted with 10 Indigenous people, newcomers and white settler individuals based on their different perspectives and experiences addressing issues of cross-cultural dialogue and exchange (Suleman, 2011). Many of these interviewees experienced the consequences of racism and negative stereotypes, and suggested possible ways for newcomers and Indigenous people to move forward. Joyce Rock, a University educated, middle class woman, states that “"elites' should not be making decisions for everyone but rather that communities should be accurately represented in order for meaningful dialogue and change to take place" (Suleman, 2011, p. 23). Joyce explains clearly how all community members need to be a part of dialogue in order to make positive changes that better reflect the people of the community. Steve Hanuse, a police officer from the Kwagulth Nation in Northern Vancouver Island, states: "building bridges between communities is not about approaching everyone the same way but about respecting people's different ways" (Suleman, 2011, p. 29). This respect for people's differences is essential to Vancouver's Dialogue Project.

There were twelve cultural exchanges where Indigenous and newcomer communities had the opportunity to invite each other to an area where they could share aspects of their culture with each other. During the cultural exchange the community welcomes participants, shares their knowledge, culture and history, and invites 
participants to partake in activities that represent them and their culture (Wong \& Fong, 2012). Some examples of the cultural visits were: Tsleil-Waututh Nation, where an ancestral forest walk was done and newcomers visited the Tsleil-Waututh Nation; Britannia Community Centre, where conversation took place with the multicultural, First Nations and Aboriginal Health practitioners to discuss traditional healing practices; and the Vancouver Aboriginal Friendship Centre, where a cultural exchange between First Nations, urban Indigenous and Mayan people of Vancouver took place as they shared stories, journey's and beats (Suleman, 2010, p. 34). These cultural exchanges provide opportunities for newcomers and Indigenous people to use their voice and decide what others should learn and know about their culture. This initiative may even encourage some people to plan return visits so they can continue making connections with each other.

The youth and elder program focuses on separate intergenerational dialogue circles. The youth were between 15-24 years old and they discussed power and privilege and ways of bridging the divide with elders (Suleman, 2011). Next, the elders and youths were placed in small groups and given a camera to capture images that reflect their group for a photo-voice project (Wong \& Baldwin, 2012). This allowed the project to not only bridge the gap between Indigenous people and newcomers but also between generations.

Lastly, newcomers and Indigenous people were interviewed in the context of the legacy project called Our Roots to talk about their experiences (Wong \& Fong, 2012). At the end of phase one, July 5.2011, an event was held to showcase the project and launch the book Vancouver Dialogues: First Nations, Urban Aboriginal and Immigrant Communities. In 2012, phase 2 began, which allowed for more cultural exchange visits, a 
book launch for the Legacy project, youth dialogue sessions, a youth summit, the creation of a how-to-guide for people to have an outline in order to provide their own cultural visits and the development of Vancouver's newcomers guide (Suleman, 2011).

The Vancouver Dialogue Project was interactive, well thought out and effective. It continues to build relationships in Vancouver by providing space and opportunities for Indigenous people and newcomers to share their experiences and perspectives. The Dialogue Project developed these relationships through a decolonized framework. A newcomer participant from Sierra Leone stated: "my journey has been about unlearning. Unlearning 'whiteness' and white privilege, unlearning self-hate, unlearning subjectivity/objectivity as an immigrant, as a black young girl, as a woman. I am learning the history of this land" (Suleman, 2011, p. 9). Thus, it is evident that newcomers and Indigenous people are working through a process of learning and unlearning within the Dialogue Project.

After the two phases of the Vancouver Dialogue Project the funding was discontinued, but the City Council began to look into the Truth and Reconciliation commission as it came to British Columbia in 2013 to conduct their public inquiry. A Reconciliation march was held in B.C. and the city created an urban Aboriginal Advisory Committee (City of Vancouver, 2018). In 2014, the City applied to the Federal Government to convene the Vancouver Immigration Partnership Project funding. The Vancouver Immigration Partnership (VIP) continues to explore how to build relationships with Indigenous people, although with more of a focus on settlement services. In 2016, during Canada 150 celebrations, the VIP collaborated with British Columbia Institution of Technology (BCIT) and Corey Wilson, the co-author of the First Peoples Guide from 
the Vancouver Dialogue Project, in order to develop online learning modules for settlement sectors (City of Vancouver, 2018). These learning modules are based on the First Peoples Guide and are designed for those working in the settlement sector to learn and recognize First Nation Communities and begin to find ways to work with them. The learning modules have been postponed due to technical difficulties BCIT was having putting the modules onto a public platform, but they hope they will be ready by early spring 2019 (City of Vancouver, 2018). After the launch of the learning modules the VIP is going to conduct a big dialogue conference for the City of Vancouver (City of Vancouver, 2018). The big dialogue will have Indigenous members, settlement sector members and settler community members present at a large roundtable event to talk and discuss possible ways to continue moving forward. Lastly, the Vancouver Dialogue Project has lasting effects as several citizenship ceremonies have taken place on reserves. It is clear that there is ongoing and continuous improvement in building relationships with the settlement sectors and Indigenous organizations within British Columbia. KAIROS Canadian Ecumenical Justice Initiatives:

KAIROS is a Greek word meaning time, it represents holy or God-given time. The term represents "a time of crisis and new possibilities" and acknowledges that the time to act for justice is now (KAIROS, 2003). KAIROS is a nonprofit organization of 10 churches and religious organizations that work towards faithful action to ecological justice and human rights (KAIROS, 2018). The organization was founded in 2001 and spans across Canada, although the two main offices are in Toronto and Ottawa. KAIROS focuses on social transformation through faith in action for justice and peace (KAIROS, 2018). Since July 2001 KAIROS has focused on programs in relation to ecological, 
gender, Indigenous and migrant justice (KAIROS, 2003). The programs they currently have in place that involves Indigenous people and newcomers is the blanket exercise, youth exchange with Guatemala and the Indigenous and newcomer friendship reconciliation events.

The blanket exercise is an interactive teaching and learning tool that was developed with Indigenous elders and teachers to allow people to learn and understand Canada's shared history. I was lucky enough to attend a KAIROS blanket exercise at the Perth Health Community Centre. The experience was unlike any other. No history book or classroom lesson can teach you like the blanket exercise does. First, an Indigenous person presented a prayer to thank the creator for the opportunity and for all living beings. After giving thanks the blanket exercise began. Everyone participating in the blanket exercise became First Nations, Inuit and later Metis people as they stepped onto the blankets on the ground that symbolized the land. The narrative walked through precontact, treaty-making, colonization and resistance. Slides with the information being said were provided in English and Spanish at both ends of the room, to ensure all participants heard and understood what was said. As the narrative explained the history of Canada, blankets were taken away or folded to symbolize the decrease or removal of land from Indigenous people. For example one slide stated:

Now hear this! According to the Indian Act of 1876 and the British North American Act of 1867, you and all your territories are now under the direct control of the Canadian federal government. You will now be placed on reserves. Please fold your blankets, until they are just large enough to stand on. (KAIROS, personal communication, August 9 2018)

People were asked to leave the blankets and sit down to symbolize Indigenous people dying due to smallpox brought over by Europeans, residential school, the high rate of 
suicide amongst Inuit people and due to the extremely high rates of tuberculosis among Indigenous communities today. At other movements during the blanket exercise people were asked to step off the blanket and stand a distance away from others to symbolize how Indigenous people were removed from their homes and placed in residential schools, to symbolize how children were taken from their homes into other homes during the 1960s scoop and for other events that separated Indigenous people physically from their home and mentally and emotionally from their culture and traditions. By physically moving amongst the space during the narrative, participants truly understand the past and still ongoing impacts the Canadian state has inflicted upon Indigenous people. During the exercise there are two KAIROS members who acted as the colonizers who removed blankets and asked participants to move or sit down. The blanket exercise is one of KAIROS's main workshops used to build relationships as it is in high demand across Canada and beyond. The blanket exercise is conducted in schools, workplaces and organizations, and is beginning to expand to the United States, Australia, Japan and Latin America, obviously with adjustments and adaptations to correspond to that country and their history.

The Youth Exchange with Guatemala is an exchange between Guatemalan youth coming to Canada and Indigenous and settler youth going to Guatemala in the summer of 2017 (KAIROS, 2018). The exchange was conducted in collaboration with other organizations in order to create authentic relationships between Indigenous and nonIndigenous people in Canada and Guatemala. The program emphasizes the importance of sharing the colonial history as a way to learn about the collective history and 
responsibility. KAIROS created this opportunity due to the common history of colonialism in Canada and Guatemala.

The reconciliation events held in March 2018, Indigenous and newcomer friendships for a just and inclusive community, are designed to build and strengthen relationships between newcomers and Indigenous people (KAIROS, 2018). Before any programming or event was developed by KAIROS, basic ideas were brought to its Indigenous Rights Circle, which includes both Indigenous leaders and non-Indigenous KAIROS members, for feedback. These events used the term friendship rather than relationship because Indigenous leaders from the Indigenous Rights Circle felt that friendship was more symbolic and less formal. The Indigenous Rights Circle was created to ensure all perspectives were heard, considered and applied. The reconciliation events were held across Canada as a way to discuss challenges and recommendations for building relationships between newcomers and Indigenous people through the use of cultural performances, workshops and gatherings.

KAIROS works towards building space so people can come in contact with one another and begin to build relationships. They support putting the time and energy into building these relationships and starting the decolonization process by providing space for these dialogues to occur. Canadian Roots Exchange (CRE):

The Canadian Roots Exchange (CRE) is a nonprofit organization that focuses on strengthening relationships between Indigenous and non-Indigenous youth (up to the age of 29) (CRE, 2014). It promotes respect, understanding and reconciliation. The main programs in place are exchanges, youth reconciliation initiative and youth conferences. 
The exchanges are about building face-to-face relationships between Indigenous and nonIndigenous youth within Canada, developing intergenerational relationships with elders, adults and children as well as sharing these experiences with their exchange community (CRE, 2014). The Youth Reconciliation Initiative (YRI) is about allowing youth to be placed at the forefront of reconciliation. It permits youth to apply for YRI recruitment, obtain week-long training before beginning to organize monthly events for youth to discuss what reconciliation means. Finally, they must share their learning through an annual conference. The youth conference takes place every year in a different city across Canada. These conferences are facilitated by youth for youth and about providing opportunities for dialogue about reconciliation, collaboration and combating negative stereotypes (CRE, 2014).

Ontario Council of Agencies Serving Immigrants (OCASI):

OCASI is a nonprofit organization formed in 1978 to advocate and act as a voice for Ontario's immigrant serving agencies (OCASI, 2017). OCASI has a volunteer board of directors to create positive change for settlement agencies. OCASI currently has a document online titled A Commitment to Truth, Justice and Reconciliation, which was created on June 21 2017. The document states how Indigenous people continue to be subjected to injustices and harm due to colonization and racist policies by the Government of Canada. It states that OCASI will begin to work towards justice and reconciliation in many different ways including building respectful relationships between Indigenous peoples, communities of colour and all others in Canada (OCASI, 2017). This document was created when the Truth and Reconciliation Commission was going across 
Canada and inviting organizations to explain what reconciliation meant to them and how they might move forward.

As the joint voice for settlement agencies, OCASI is pushing for funding and resources so that settlement services can provide additional programming about Indigenous people and their history. Many newcomers go to an agency for referrals in order to obtain housing, employment and other related matters, so settlement agencies' main mandates are in relation these concerns, leaving Indigenous knowledge, history and voices unacknowledged and unaddressed (participant). Therefore, OCASI is fighting for the TRC calls to action to be addressed and contributing to the citizenship guide booklet that is a part of number 93 call to action (participant). OCASI also works towards encouraging settlement services to build their own understanding of what it means to reconcile and encourages settlement service provides to participate in cultural competency training. OCASI is not only the voice that connects the federal government with settlement services to promote funding and programming for newcomers and Indigenous people, but also strives to understand their own role as a non-Indigenous organization (participant).

OCASI tries to promote settlement organizations in developing relationships with Indigenous organizations and people. Currently, OCASI is developing connections with the Ontario Federation of Indigenous Friendship Centre to provide cultural competency training for OCASI staff members (participant). It completed the first phase and will continue the cultural competency training this September. OCASI believes that it is essential to dedicate their own internal resources for capacity building alongside 
advocating for the development of these relationships within Ontario's settlement services.

\section{COSTI Immigration Services:}

COSTI is a community based multicultural settlement service agency in Toronto that is at the beginning stages of developing relationships with Indigenous organizations and people. There are 18 locations in Toronto, the Region of Peel and York Region that are currently providing employment, education, English language program, settlement

and social services to newcomers in need of assistance (COSTI, 2017). COSTI originally thought of their work, as a service for newcomers and therefore, the organization did not see the benefit of working with Indigenous organizations. It was through the call to action by the Truth and Reconciliation Commission that COSTI realized that there is a role for them to play and that all Canadians need to reconcile with Indigenous communities. COSTI has a role to ensure newcomers are educated about Indigenous people and their history, and in order to do so COSTI needs to establish relationships with Indigenous communities. Currently they are at the planning stage, after the calls to action they began thinking about what role they play in this effort and how they will go about responding to it. The first step for COSTI is to educate its staff; the second step is to explore how to integrate Indigenous information into different aspects of their work such as within the language program (participant). Additionally, COSTI noted how essential it is that they work alongside Indigenous communities and leaders on the programming and information that they hope to put in place for newcomers in the future. 


\section{Benefits, Challenges and Next Steps for the Future}

During the interviews, each organization (except KNK) was asked about the benefits and challenges of building relationships with Indigenous organizations and people in order to develop programming and information for newcomers. They were also asked about how they could involve Indigenous organization and leaders to a greater degree. Most participants were in consensus that the benefits of developing these relationships is the opportunity to become aware, learn, unlearn, understand, engage with communities and begin the conversation that has been absent for so long. The challenges stressed were resources and funding, lack of understanding and discomfort, and the multifaceted issues within newcomer and Indigenous people's communities. In order to expand these relationships the participants stressed that they needed to continue to create dialogue and learn what they can from each other to create true partnerships, begin to involve Indigenous people within organizations at all levels, educate the staff and create local links.

$\underline{\text { Benefits to Building Relationships between Settlement Services and Indigenous }}$ Organizations:

A consensus between KAIROS, Vancouver Dialogue Project, OCASI, COSTI and Canadian Roots Exchange was that developing relationships between newcomers and Indigenous people within organizations is essential and beneficial because of the learning and understanding it provides for all involved. In order to create these relationships and benefit from them newcomers and non-Indigenous people must be learning.

Learning from one another, is the only way we can have meaningful relationships and hopefully we can understand one another. So when there's a need to support one another we will know why we are doing it. And of course, being in a relationship and a respectful relationship with 
one another is key. (Andrew, participant)

The learning that is taking place when developing these relationships is seen to be different from that of a textbook or classroom. The learning is beyond that of an intellectual exercise, which makes it impactful for all those involved (Andrew, participant). These relationships allow the truth to be known and for newcomers as well as other non-Indigenous people within organizations to become educated. Starting this conversation is essential because it is seen as the first step to decolonization. Andrew explained how, "we are doing the settling, we are settlers -- so we need to understand that role in that relationship and be comfortable to advocate when in situations." Dialogues between newcomers and Indigenous people as well as between Indigenous organizations and other organizations are helping to develop these relationships and allow settlers to be comfortable with being uncomfortable.

By creating opportunities to learn about Indigenous people and Canada's history, settlers can begin to understand the importance of acknowledging this information, which will allow settlement services to start decolonizing and continue to develop relationships alongside Indigenous organizations. As Bob explained, "we need to rectify wrongs from the past, it's not just rectifying those wrongs by saying you know we need to do things differently, we need to understand Indigenous communities." Indigenous people in the past were the welcomers of this country and did so with pride and generosity, by working towards developing these relationships and starting this dialogue settlement services can help to make Indigenous people the welcomers of Canada again. Jim explained how the Indigenous people who worked alongside Chinese railroad workers during the development of the Canadian Pacific Railway created a cemetery for the Chinese people 
who died. Due to the horrible situations and circumstances of danger building the railway many Chinese workers died and were left unburied, but the Indigenous people of the time allocated land on their own reserves for these people to be buried. "These are known parts of history that we need to share back with the immigrant groups and change those histories" (Jim, participant). Making these historical facts known can allow Canadians and newcomers to understand how Indigenous people are a significant part of our identity as a country that has been ignored for far to long (Bob, participant).

Creating awareness by engaging with communities and starting the dialogue is a significant benefit that needs to continue to evolve so Indigenous people are known and become the welcomers of Canada. As Mary mentioned, "a lot of it is shock or unlearning and relearning and reimagining their new homeland." The steps to unlearning, relearning and reimagining are extremely beneficial because they allow for relationships to be developed based on the fundamentals of truth, respect and openness.

Challenges of Building Relationships between Settlement Services and Indigenous Organizations:

An ongoing struggle organizations often deal with is the lack of funding and resources provided by federal, provincial and municipal governments. As a participant identified: "there is so much interest out there but we just do not have the time or resources" (Andrew, participant). Suzanne also stated that settlement organizations are always stretched for resources. To integrate Indigenous knowledge and history and develop these relationships to do so can be demanding and difficult for these organizations without the extra funding and resources (Bob, participant). The funding can also deter or limit the ability to develop these relationships because it often leads 
organizations to expect Indigenous knowledge and collaboration on a volunteer basis.

Andrew explains:

there should be resources available for settlement organizations to hire Indigenous leaders and educators to work with them. Not to bring them on a volunteer basis, which is not only a challenge, but a problem, when we want especially the settlement sector to be involved because their funds are so limited. (Andrew, participant)

Expecting Indigenous people to want to build relationships and develop these programs alongside settlement services or other nonprofit organizations for free is detrimental because as a society we need to begin to value people's time and knowledge. It should not be assumed that Indigenous people will volunteer their time simply because they are committed to reconciliation and building relationships. This type of thinking hinders the relationship building process and exploits Indigenous people.

Another challenge that participants brought up in terms of time and resources was how the Truth and Reconciliation Commission has increased the interest in building relationships with Indigenous people. Bob stated that:

The Indigenous community is inundated with requests. And I think that maybe the TRC has created you know a huge interest, which is what I'm glad to see, that is what should have happened, but I think that everybody is probably going to the same people and I'm finding, like, I'm talking to people who say well the earliest I could do anything for you is like January, February next year. (Bob, participant)

So, many organizations are finding it hard to begin the process of developing relationships with Indigenous organizations because of the overwhelming amount of requests Indigenous people and organizations are receiving.

Another challenge presented is the lack of understanding by the state. Often it is not newcomers or non-Indigenous people who are not unwilling to understand but it's the government or state. Andrew (participant) explained that "it's that lack of understanding, 
there is no political will in our elected officials in every level; municipal, provincial, federal. There is no political will to support this kind of relationship programs because they don't see it as a priority." The lack of interest and knowledge by government prohibits others from being able to understand and learn because if it is not deemed important then few resources and funding will be allocated to the development of programs that connect Indigenous people and newcomers. If the government does not value Indigenous knowledge, history and relationship building then it makes it difficult for settlement services and other nonprofit organizations to independently create opportunities for interactions between newcomers and Indigenous people that allow for authentic relationships to be developed and misconceptions to be debunked.

The next challenge proposed is how settlers and newcomers locate themselves within this discussion and process and the level of discomfort that often occurs from this learning experience. Suzanne explained that understanding how we, as settlers, position ourselves during this learning process, that can make feelings of discomfort, is not necessarily a challenge but a reality. She explains that settlers must think about how we position ourselves individually and as a group because "even among Indigenous people there isn't one common understanding of relationships with historic settlers or with the Crown" (participant). This situation can make it difficult to understand for settlers placement within these relationships, as newcomers or non-Indigenous people, which often leads to a level of discomfort as settlers understand Canada's past and begin to think about who we are, where we stand and what does it mean to build a relationship with Indigenous people. Thus, organizations need to begin to think about how we can bridge this level of discomfort, accept it and begin to relearn. 
Lastly, newcomers and Indigenous people have their own challenges within their respective communities, which can make building relationship multifaceted. As Mary explains organizations need to meet people where they are at because "communities are dealing with a lot within their own communities and on their own, there is a healing process and things they need to do within themselves" (participant). Recognizing the multi-faceted issues within individuals and their community is significant before building relationships outside of these communities.

In conclusion, there are many challenges that settlement services and nonprofit organizations face as they go about this journey of connecting with Indigenous organizations and people in order to begin building authentic relationships between newcomers and Indigenous people. Challenges are never easy to overcome but they are significant to identify, so that change can begin to tackle these obstacles.

Next Steps for Settlement Services:

Continuing the dialogue between Indigenous people, newcomers and other nonIndigenous people is essential to decolonizing settlement services. Organizations cannot start conversations with Indigenous organizations, for the sole purpose of filling a mandate. Dialogue is a part of the development of these relationships. It is an ongoing process that needs to be adapted, continued and fine tuned as settlement services begin to learn more and more. If the process stops, the trust and respect that was built will be jeopardized and tainted. Jim states that at the big dialogue conference newcomer leaders, and Indigenous community leaders will come together to talk about what can be learned from each other and how Indigenous people, non-Indigenous people and newcomers can continue to develop these relationships (participant). Events like these allow unlikely 
groups of people to have an opportunity to meet, discuss and learn from each other as well as create plans that include multiple perspectives.

Several interviewees re-instated how important it is to create true partnerships. Andrew explains that if organizations work together and put programs in place together, this action and collaboration are where these partnerships can flourish. He offers a simple example to show the importance of action over words and explains that he can say sorry to me for something he did but if he continues the same actions that hurt me in the first place, his words mean nothing. Therefore, it is:

not to do things when I want and [when organization] wants, it is to do things when people are ready, so we meet, that to me is the true spirit of partnership. Otherwise, it would be [the organization] going and doing exactly the same thing that has been done for centuries, which is to impose things and we can't do that. (Andrew, participant)

Andrew explains how organizations and people must learn through discussions because if we are listening but not learning, the same cycle of colonization will continue.

All organizations stressed that Indigenous people must be involved at multiple levels to ensure all dialogue and programming is developed with an Indigenous worldview and perspective. Andrew explained why this is important:

if we are working on Indigenous rights issues we need to have Indigenous people on staff. We need to work more with Indigenous people, constantly consult with them, constantly collaborate with them. Anytime I have an idea, it may be good to me but I need to check that with the people I need to work with. (participant)

If programming is done for newcomers and Indigenous people then it is essential to include newcomers and Indigenous people and their perspectives. Creating a program for people without their consultation would be useless and even detrimental. One participant explained how their organization has several Indigenous people on payroll. Suzanne also 
stressed the importance of involving Indigenous people in all activities and programs.

With this in mind, settlement services must ensure that Indigenous people are not an afterthought but that the information, activities and programs in place are developed by Indigenous people so that their knowledge and voices are at the forefront (Bob, participant). Bob reiterated this statement when he said:

the involvement of...the....leaders within the Indigenous community to, to ensure that what we are doing is not our perception of what we should be doing but ensuring that they feel yes, this is what I would want newcomers to know about us. (participant)

Bob rationalized how its important to educate the staff before developing materials or integrating Indigenous knowledge into settlement services because settlement workers cannot be providing adequate information to newcomers if they are unaware and misinformed themselves (Bob, participant).

Finally, we must ensure that local links are created. Each country, province, city and town will have different organizations, different treaties and different groups of Indigenous people. Therefore, it is essential for settlement services and nonprofit organizations to make these connections with those around them. Mary said: "making those connections to have groups come in locally to talk about whether it's a specific treaty or history and having those educational opportunities are really important" (Participant). Each town, province and country will have different information, histories, knowledge, and ways to build relationships. The benefits and challenges may be similar but the local links and connections will make the relationships and programs unique and meaningful to that region or area.

Across Canada there is still a considerable amount of progress to be made within settlement services and nonprofit organizations in order for them to work alongside 
Indigenous organizations and people to create relationships and programming that acknowledges and appreciates Indigenous knowledge, history and voices as well as units Indigenous people and newcomers.

\section{RECOMMENDATIONS AND CONCLUSIONS}

In order for settlement services and nonprofit organizations to work alongside Indigenous organizations to build relationships between newcomers and Indigenous people the support and involvement of the federal, provincial and municipal governments is essential. Mary proposed some important questions that she believes the government needs to consider: "What are we sharing about this nation to new communities and who's voices are being heard in this process?" Indigenous people have played a big role in what Canada is now. Andrew strongly recommends that all levels of government get involved because they all have a role to play that will help better the relationships between Indigenous and non-Indigenous people. The government needs to support settlement services and nonprofit organizations by providing funding so that organizations can began hiring Indigenous staff. Too often Indigenous people are hired or asked to volunteer for one day or for a special event but Andrew says it should not be treated as a special event, but rather an everyday process. When Indigenous people become staff within settlement services and nonprofit organizations their perspectives and knowledge can be valued and involved everyday.

Andrew, Suzanne and Bob believe that the government needs to focus on implementing the Truth and Reconciliation calls to action. The calls to action, more specifically number 93 and 94, need to be addressed to better inform newcomers. These two calls to action ask for the government to add treaties into the citizenship oath and to 
revise the information kits and citizenship test newcomers take. These changes are important because even though they seem like "small things [they] make a huge difference" (Andrew, participant). Government could make it mandatory with proper funding for settlement services and nonprofit organizations to build relationships with Indigenous organizations to provide proper information, workshops and programs to newcomers. However, this could also lead settlement services to becoming obligated to build these relationships in order to obtain funding and provide these programs, which could make the relationships less authentic and place a large burden on Indigenous organizations.

Jim suggested that the government could allot a certain amount of money to settlement services so that they could provide programming that involves Indigenous people and newcomers but that each settlement service could write a proposal. He suggested that the proposal would explain how and what they will be doing in order to involve Indigenous organizations alongside their services. Andrew added that when writing the proposal the settlement service would have to build a relationship with an Indigenous organization or person in order to get proper feedback on their program ideas presented within the proposal before submitting them. Therefore, Indigenous organizations and people need to be involved in each step of the process when developing programs for Indigenous people and newcomers.

If Indigenous people begin to be continuously involved in the welcoming process through settlement services, it could allow the federal government to realize the importance of involving Indigenous leaders across Canada within immigration policy decision-making. This land belongs to Indigenous people; therefore, they should be the 
people who are consulted and involved in the decision making process in relation to settlement policy. As Bob states, Indigenous people are not saying that newcomers should not be coming to Canada; they simply want newcomers to be informed of their people and their land. So, settlement services should be required to incorporate Indigenous knowledge and voices so newcomers can be informed. This should be a requirement and a part of the integration process that newcomers go through. Therefore, Indigenous people should be a part of the settlement policy and the pre-arrival process in order to emphasize Indigenous knowledge and perspectives into Canada's national identity and to allow Indigenous people to be the welcomers of Canada.

Settlement services need to begin by educating themselves about Indigenous history and culture, begin to seek opportunities to get to know Indigenous people within their communities, start to find out what Indigenous leaders are calling for, and finally, begin to make educated political, social, economic, and personal choices, which ensure the retention, protection, and advancement of Indigenous knowledge, history and voices (Khan, Alan, Pennington \& Richardsons, 2015, p. 151). Settlement services are designed to integrate newcomers, but that does not mean Indigenous knowledge, history and voices are absent, they should be at the forefront, made a priority. This process is not only essential for settlement services but for nonprofit organizations, individuals and the government to start standing beside Indigenous people and their goals.

Within this Major Research Paper, I emphasized the importance of involving Indigenous people and their stories into settlement services in order to allow them to be placed at the forefront of Canada by becoming the welcomers of Canada. When 
Indigenous people are considered people with rights rather than minorities with problems, then transformation is possible (Fleras \& Maaka, 2010, p.1).

In conclusion, the critical literature review demonstrated how part of Canada's national identity, multiculturalism, excludes and ignores Indigenous people. A main component of multiculturalism is integration. Therefore, settlement services mandates are often to work towards integrating newcomers into Canada. When newcomers are integrated into Canada's colonial system they become settlers and often reproduce negative misconceptions about Indigenous people. These negative stereotypes continue to keep newcomers and Indigenous people divided. Therefore, it is essential that the settlement services and nonprofit organizations begin to work alongside Indigenous organizations and people. It is significant to incorporate Indigenous people, knowledge and voices into the information, workshops, and programs for newcomers. Collaboration between these organizations helps to create space for Indigenous people and newcomers to start the dialogue. This process can be challenging, but as long as both organizations are transforming and working through this process together to build authentic relationships, change is imaginable for Canada's national identity, for settlement services and for Indigenous people. 
APPENDIX

1. What is the extent and nature of your organizations work in relation to Indigenous people and newcomers?

2. What benefits have you observed/recorded so far from this collaboration and from the programs currently in place? Why is it beneficial for your organization to create programming involving Indigenous people and newcomers?

3. What are some of the challenges your organization faces in relation to building relationships with Indigenous people and newcomers? Or with building relationships with Indigenous organizations?

4. What prevents you from being able to provide programs for Indigenous people and newcomers?

5. How can your organization further involve Indigenous organizations and people to a greater degree than you currently are?

6. What recommendations do you have for the federal government in relation to involving Indigenous organizations alongside settlement services for newcomers? 


\section{REFERENCES}

Abu-Laban, Y., Gabriel, C. (2002). Selling Diversity: Immigration, Multiculturalism, Employment, Equity, and Globalization. Peterborough: Broadview Press.

Alfred, T. (2017). It's All about the Land. In P. M. Editor \& N.S Editor (Eds.), Whose Land is it Anyway? (10-13). British Columbia: Federation of Post Secondary Educators of BC.

Alfred, T., Corntassel, J. (2005). Being Indigenous: Resurgence against Contemporary Colonialism. Government \& Opposition, 40, 597-614.

Bannerji, H. (2000). The Dark Side of the Nation: Essays on Multiculturalism, Nationalism and Gender. Toronto: Canadian Scholars' Press.

Bauder, H. (2011). Closing the immigration-Aboriginal parallax gap. Geoforum, 42(5), 517-519.

Borrows, J. (1997). Wampum at Niagara: The Royal Proclamation, Canadian Legal History, and Self-Government. In Aboriginal and Treaty Rights in Canada: Essays on Law, Equality, and Respect for Difference. Vancouver: University of British Columbia Press, 1997. Retrieved from https://www.sfu.ca/ palys/Borrows-WampumAtNiagara.pdf

Canadian Council for Refugees. (2017). 2017 Immigration Levels- Comments. Canadian Council for Refugees. Retrieved from http://ccrweb.ca/en/2017-immigrationlevels-comments

City of Vancouver. (2018). Vancouver Immigration Partnership. Retrieved from https://www.vancouverimmigrationpartnership.ca

Cheadle, B. (2012). First Nations consulted on 2013 Immigration Targets as Tories Break New Ground. Canadian Press.

Coulthard, G. (2014). Red Skin White Masks: Rejecting the Colonial Politics of Recognition. University of Minnesota Press: Minneapolis and London.

Chung, M. M. L. (2012). The Relationships between Racialized Immigrants and Indigenous Peoples in Canada: A Literature Review. (Master's Dissertation). $1-62$.

Corntassel, J. (2012). Re-envisioning Resurgence: Indigenous pathways to decolonization and sustainable self-determination. Decolonization: Indigeneity, Education \& Society, 1(1), 86-101.

COSTI. (2017). Who we are. COSTI. Retrieved from 
http://www.costi.org/whoweare/whoweare.php

Dhamoon, R. (2015). A Feminist Approach to Decolonizing Anti-Racism: Rethinking Transnationalism, Intersectionality, and Settler Colonialism. Feral Feminisms, 4, 20-37.

DeLeeuw, S., Greenwood, Lindsay, N. (2013). Troubling Good intentions. Settler Colonial Studies. 3, 3-4.

Dmytriw, A. (2016). Decolonizing Immigration: Addressing Missing Indigenous Perspectives in Canadian Immigration Policies. (Master's Dissertation). 1-71.

Fleras, A. Maaka, R. (2010). Indigeneity-Grounded Analysis (IGA) as Policy (-Making) Lens: New Zealand Models, Canadian Realities. The International Indigenous Policy Journal, 1(4), 1-34.

Ghorayshi, P. (2010). Diversity and Interculturalism: Learning from Winnipeg's Inner City. Canadian Journal of Urban Research, 19(1), 89-104.

Godlewska, A., Moore, J., Bednasek, D.C. (2010). Cultivating Ignorance of Aboriginal Realities. The Canadian Geographer, 54(4), 417-440.

Gooder, C. (2017). Immigration, Ethnic Diversity and Cities: A Literature Review for Auckland Council. Auckland Council.

Green, J. (2016). Enacting Reconciliation. Proceedings from Canadian Political Science Association Conference. Calgary, Alberta. May 31st to June 2nd, 2016.

Gyepi-Garbrah, J. (2010). Understanding Diversity and Interculturalism between Aboriginal Peoples and Newcomers in Winnipeg. (Master's Thesis, University of Saskatchewan). 1-138.

Gyepi-Garbrah, J., Walker, R., Garcea, J. (2014). Indigeneity, Immigrant Newcomers and Interculturalism in Winnipeg, Canada. Urban Studies, 51(9). 1795-1811.

KAIROS. (2003). KAIROS: Another Kind of Time. KAIROS: Canadian Ecumenical Justice Initiatives.

KAIROS. (2018). What we do: Indigenous Rights. Faithful Action for Justice. Retrieved from https://www.kairoscanada.org/what-we-do/indigenous-rights

KAIROS. (August 9. 2018). Blanket Exercise. Personal Communication.

Kang, H. (2017). Know Your Treaty!

Dish with One Spoon. Canadian Roots Exchange Treaties Workshop.

Retrieved from https://prezi.com/3y4nulnuj_r3/know-your- 
treaty-dish-with-one-spoon/

Kasparian, S. (2012). Introduction: Aboriginal Peoples: Canada's First Welcoming Community where do Aboriginal-Immigrant Relations Stand Today? Canadian Issues, 3-8.

Keefer, T. (2014). A short introduction to the Two Row Wampum, Briarpatch. Retrieved from https://briarpatchmagazine.com/articles/view/a-short-introduction-to-thetwo-row-wampum

Khan, S., Alan, R., Pennington, J., Richardson, L. (2015). Paying our Dues: The Importance of Newcomer Solidarity with the Indigenous Movement for SelfDetermination in Canada. The Canadian Journal of Native Studies, 35(1): 145153.

KNK (2017). Ka Ni Kanichihk. Retrieved from http://www.kanikanichihk.ca/programs/

Kunz, J., Sykes, S. (2007). From Mosaic to Harmony: Multicultural Canada in the 21. Century: Results of Regional Roundtables. PRI Project Cultural Diversity. 1-25.

Kymlicka, W. (1988). Finding our Ways: Rethinking Ethnocultural Relations in Canada. Toronto: Oxford University Press.

Laucius, J. (2015). There will be some hard things said: Muslim group hears about Truth

Lawrence, B., Dua, E. (2005). Decolonizing Antiracism. Social Justice Race, Racism, and Empire: Reflections on Canada, 32(4), 120-143.

Lowman, E. B., Barker, A. J. (2015). Settler: Identity and Colonialism in 21. Century Canada. Halifax \& Winnipeg: Fernwood Publishing.

MacDonald, D. B. (2014). Aboriginal Peoples and Multicultural Reform in Canada: Prospects for a New Binational Society. Canadian Journal of Sociology, 39(1).

Manuel, A. (2017). From Dispossession to Dependency. In P. M. Editor \& N.S Editor (Eds.), Whose Land is it Anyway? (10-13). British Columbia: Federation of Post Secondary Educators of BC.

Marks, D. (2014). What's in a name: Indian, Native, Aboriginal or Indigenous? $C B C$ News. Retrieved from https://www.cbc.ca/news/canada/manitoba/what-s-in-aname-indian-native-aboriginal-or-indigenous-1.2784518

Memmi, A. (1991). The colonizer and the colonized. Boston, MA: Beacon Press.

Neuman, W. L. (2006). Social research methods: Qualitative and quantitative approaches (6th ed.) Pearson/Allyn and Bacon. 
OCASI. (2017). A Commitment to Truth and Reconciliation. Policy: Integration and Settlement. Retrieved from http://www.ocasi.org/commitment-truth-andreconciliation.

Onondaga Nation. (2018). Two Row Wampum- Guswenta. Onondaga Nation: People of the Hills. Retrieved from http://www.onondaganation.org/culture/wampum/tworow-wampum-belt-guswenta/

Palmater, P. (2017). Decolonization is Taking Back our Power. In P. M. Editor \& N.S Editor (Eds.), Whose Land is it Anyway? (10-13). British Columbia: Federation of Post Secondary Educators of BC.

Rafiquddin, S. (2017). Journalist bridges connection between refugees and Indigneous people. CBC News. Retrieved from http://www.cbc.ca/news/canada/britishcolumbia/journalist-bridges-connection-between-refugees-and-indigenous-people1.4115311

Rheault, A. (2011). Solving the "Indian Problem." Assimilation Laws, Practices \& Indian Residential Schools. Ontario Metis Family Records Center. Retrieved from https://www.omfrc.org/wp-content/uploads/2016/06/specialedition8.pdf

Root, J. (2014). Bridging the Parallax Gap: Settler-Colonialism and the Relationship between Indigenous Peoples and Racialized Migrants in Canada. (Masters Dissertation) 1-65.

Simpson, L. (2011). Dancing on our Turtle's Back: Stories of Nishnaabeg Re-creation, Resurgence, and a new Emergence. Winnipeg: Arbeiter Ring Publishing.

Sium, A., Desai, C., Ritskes, E. (2012). Towards the 'tangible unknown': Decolonization and the Indigenous Future. Decolonization, Indigeneity, Education \& Society, 1(1): $1-13$.

Sharma, N., Wright, C. (2008/2009). Decolonizing Resistance, Challenging Colonial States. Social Justice, 35(3),120 -138.

Smith, A. (2012). Indigeneity, Settler Colonialism, White Supremacy. In D.M. HoSang, L. Oneka, \& L. Pulido, Racial Formation in the Twenty First Century. Berkeley: University of California Press.

Snelgrove, C., Dhamoon, R., Corntassel, J. (2014). Unsettling settler colonialism: The discourse and politics of settlers, and solidarity with Indigenous nations.

Decolonization: Indigeneity, Education \& Society. 3(2). 1-32.

Stanley, A., Arat-Koc, S. Bertram, L., King, H. (2014). Intervention-'Addressing the Indigenous-Immigration "Parallax Gap"". Antipode Foundation. Retrieved from 
https://antipodefoundation.org/2014/06/18/addressing-the-indigenousimmigration-parallax-gap/

Suleman, Z. (2011). Vancouver Dialogues: First Nations, Urban Aboriginal, and Immigrant Communities. Social Policy. 1-63.

Tremonti, A (Producer). (2018, June 29). How overcoming adversity brought together a Syrian teen and Mi'kmaq grandmother [Audio Podcast]. The Current. Retrieved from http://www.cbc.ca/listen/shows/the-current/segment/15553671

Truth and Reconciliation Commission of Canada (2015). Truth and Reconciliation Commission of Canada: Calls to Action. 1-11. Retrieved from http://www.trc.ca/websites/trcinstitution/File/2015/Findings/Calls to Action Eng lish2.pdf

Truth and Reconciliation Commission of Canada (2015). Honouring the Truth, Reconciling for the Future: Summary of the Final Report of the Truth and Reconciliation Commission of Canada.

Tuck, E. Yang, K.W. (2012). Decolonization is not a Metaphor. Decolonization: Indigeneity, Education \& Society, 1(1), 1-40.

Union of Ontario Indians. (2013). An Overview of the Indian Residential School System. $1-8$.

Voyageur, C. J., Calliou, B. (2001). Various Shades of Red: Diversity within Canada's Indigenous Community. The London Journal of Canadian Studies. 16, 103-118.

Walia, H. (2012). Decolonizing Together: Moving beyond a politics of solidarity toward a practice of decolonization. BriarPatch. Retrieved from https://briarpatchmagazine.com/articles/view/decolonizing-together

Winter, E. (2007). Bridging Unequal Relations, Ethnic Diversity, and the dream of Unified Nationhood: Multiculturalism in Canada. Zeitschrift fur Kanadastudien, 27(1). 38-57.

Wolfe, P. (2006) Settler Colonialism and the Elimination of the Native. Journal of Genocide Research, 8(4), 387-409.

Wong, B., Fong, K. (2012). Dialogues between First Nations, Urban Aboriginals and Immigrant Communities in Vancouver. Canadian Issues, 19-23.

Wotherspoon, T., Hansen, J. (2013). The "Idle No More" Movement: Paradoxes of First Nations Inclusion in the Canadian Context. Social Inclusion, 1(1), 21-36.

Yoshida, I. (2014). Dis-cover Canada: A Critical Discourse Analysis of Canada's 
Citizenship Guidebook for Immigrants and the Making of Settler Colonial Subjects. (Master's Thesis, University of Toronto). 1-121. 
